Provided for non-commercial research and education use. Not for reproduction, distribution or commercial use.

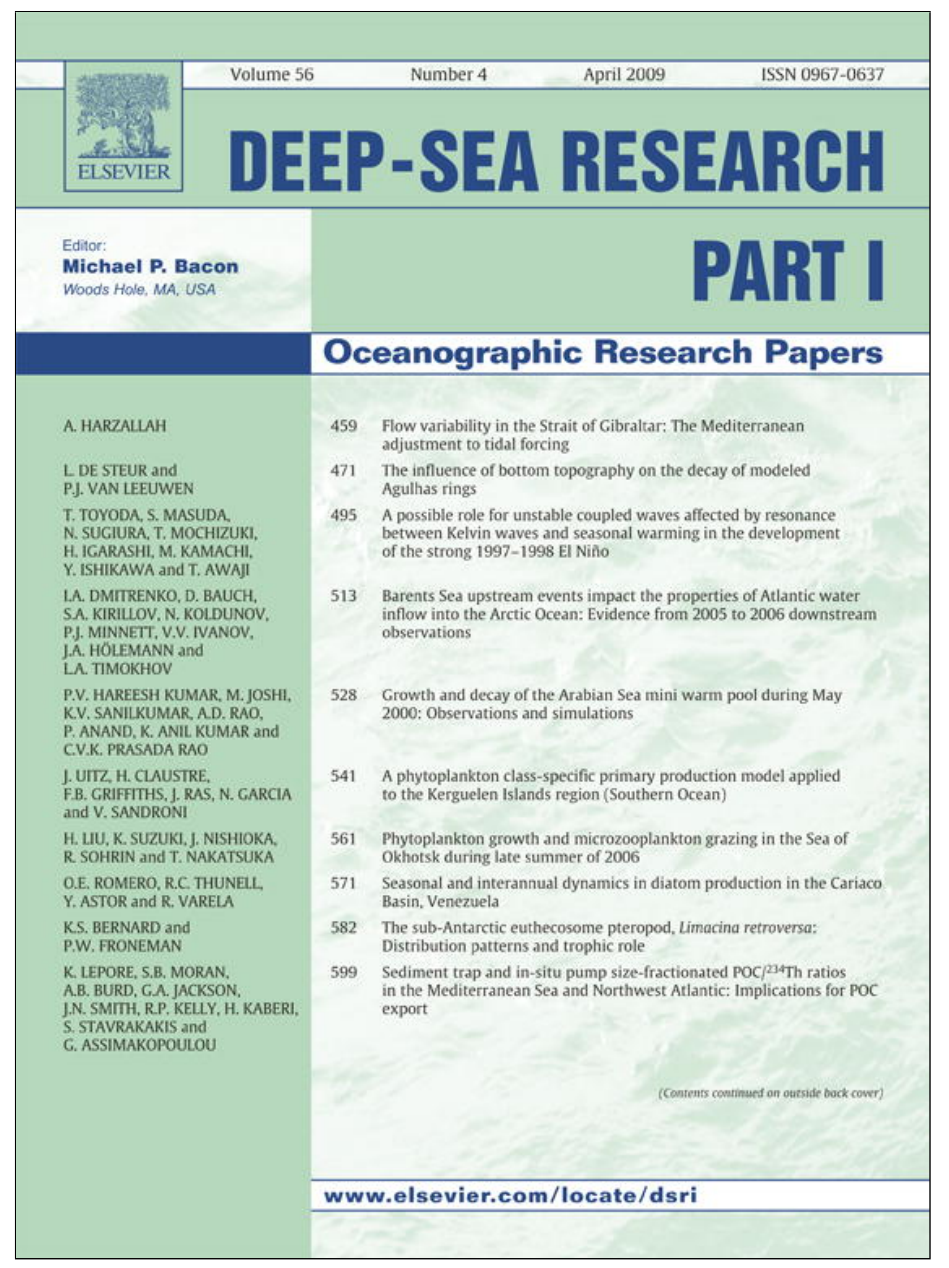

This article appeared in a journal published by Elsevier. The attached copy is furnished to the author for internal non-commercial research and education use, including for instruction at the authors institution and sharing with colleagues.

Other uses, including reproduction and distribution, or selling or licensing copies, or posting to personal, institutional or third party websites are prohibited.

In most cases authors are permitted to post their version of the article (e.g. in Word or Tex form) to their personal website or institutional repository. Authors requiring further information regarding Elsevier's archiving and manuscript policies are encouraged to visit:

http://www.elsevier.com/copyright 


\title{
Barents Sea upstream events impact the properties of Atlantic water inflow into the Arctic Ocean: Evidence from 2005 to 2006 downstream observations
}

\author{
Igor A. Dmitrenko ${ }^{a, *}$, Dorothea Bauch ${ }^{a}$, Sergey A. Kirillov ${ }^{b}$, Nikolay Koldunov ${ }^{c, d}$, \\ Peter J. Minnett ${ }^{\mathrm{e}}$, Vladimir V. Ivanov ${ }^{\mathrm{f}}$, Jens A. Hölemann ${ }^{\mathrm{g}}$, Leonid A. Timokhov ${ }^{\mathrm{b}}$ \\ a Leibniz Institute of Marine Sciences, University of Kiel, Kiel, Wischhofstr. 1-3, Building 4, 24148 Kiel Germany \\ ${ }^{\mathrm{b}}$ Arctic and Antarctic Research Institute, St. Petersburg, Russian Federation \\ ${ }^{\mathrm{c}}$ Institute of Oceanography, Centre for Marine and Atmospheric Sciences, University of Hamburg, Hamburg, Germany \\ ${ }^{\mathrm{d}}$ International Max Planck Research School on Earth System Modelling, Hamburg, Germany \\ ${ }^{\mathrm{e}}$ Rosenstiel School of Marine and Atmospheric Science, University of Miami, Miami, FL, USA \\ ${ }^{\mathrm{f}}$ International Arctic Research Center, University of Alaska Fairbanks, Fairbanks, AK, USA \\ ${ }^{g}$ Alfred Wegener Institute for Polar and Marine Research, Bremerhaven, Germany
}

\section{A R T I C L E I N F O}

\section{Article history:}

Received 3 March 2008

Received in revised form

3 November 2008

Accepted 10 November 2008

Available online 27 November 2008

Keywords:

Atlantic water

Arctic Ocean

Barents Sea water inflow

Ice and atmospheric forcing

\begin{abstract}
A B S T R A C T
Inflow of Atlantic water (AW) from Fram Strait and the Barents Sea into the Arctic Ocean conditions the intermediate (100-1000 m) waters of the Arctic Ocean Eurasian margins. While over the Siberian margin the Fram Strait AW branch (FSBW) has exhibited continuous dramatic warming beginning in 2004, the tendency of the Barents Sea AW branch (BSBW) has remained poorly known. Here we document the contrary cooling tendency of the BSBW through the analysis of observational data collected from the icebreaker Kapitan Dranitsyn over the continental slope of the Eurasian Basin in 2005 and 2006. The CTD data from the R.V. Polarstern cruise in 1995 were used as a reference point for evaluating external atmospheric and sea-ice forcing and oxygen isotope analysis. Our data show that in 2006 the BSBW core was saltier (by $\sim 0.037$ ), cooler (by $\sim 0.41{ }^{\circ} \mathrm{C}$ ), denser (by $\sim 0.04 \mathrm{~kg} / \mathrm{m}^{3}$ ), deeper (by $150-200 \mathrm{~m}$ ), and relatively better ventilated (by $7-8 \mu \mathrm{mol} / \mathrm{kg}$ of dissolved oxygen, or by $1.1-1.7 \%$ of saturation) compared with 2005. We hypothesize that the shift of the meridional wind from off-shore to onshore direction during the BSBW translation through the Barents and northern Kara seas results in longer surface residence time for the BSBW sampled in 2006 compared with samples from 2005. The cooler, more saline, and better-ventilated BSBW sampled in 2006 may result from longer upstream translation through the Barents and northern Kara seas where the BSBW was modified by sea-ice formation and interaction with atmosphere. The data for stable oxygen isotopes from 1995 and 2006 reveals amplified brine modification of the BSBW core sampled downstream in 2006, which supports the assumption of an increased upstream residence time as indicated by wind patterns and dissolved oxygen values.
\end{abstract}

(c) 2008 Elsevier Ltd. All rights reserved.

\footnotetext{
* Corresponding author. Tel.: +494316002858; fax: +49431132850

E-mail address: idmitrenko@ifm-geomar.de (I.A. Dmitrenko).
}

\section{Introduction}

The intermediate waters of the Arctic Ocean's Nansen Basin continental margins are influenced by the confluence of the warm and saline Atlantic water (AW) inflow 
through Fram Strait with the relatively colder and slightly fresher AW inflow through the Barents Sea that enters the Arctic Ocean between Franz Josef Land and Severnaya Zemlya (Rudels et al., 1994; Fig. 1). The difference in characteristics between the Fram Strait branch of AW (FSBW) and the Barents Sea branch of AW (BSBW) is explained mainly by the BSBW's air-sea interactions over the Barents Sea shelf, by which it is cooled and better ventilated (Schauer et al., 2002a, b; Falkner et al., 2005), and its interaction with the fresher Norwegian Coastal Current (Schauer et al., 2002a,b). The merged AW branches sink to an intermediate (150-900 m) level and mix vigorously, following the Eurasian Basin bathymetry in a cyclonic sense as a narrow, topographically-trapped boundary current (Timofeev, 1957; Aagaard, 1989; Woodgate et al., 2001; Schauer et al., 2002b; Karcher et al., 2003; Polyakov et al., 2005; Dmitrenko et al., 2008a). The cooler and fresher BSBW is traceable along the continental slope of the western Laptev Sea, the area located directly downstream of the FSBW and BSBW confluence in the northern Kara Sea over a depth range of 400-1100 m (Schauer et al., 2002a, b). The BSBW also remains recognizable in the Canada Basin (McLaughlin et al., 2002; Woodgate et al., 2007).

Over the past several decades the FSBW has exhibited substantial variability. Shifts in atmospheric circulation patterns have resulted in increased transport and temperature of AW entering the Arctic via Fram Strait (Rudels et al., 2000). The first evidence of strong warming within

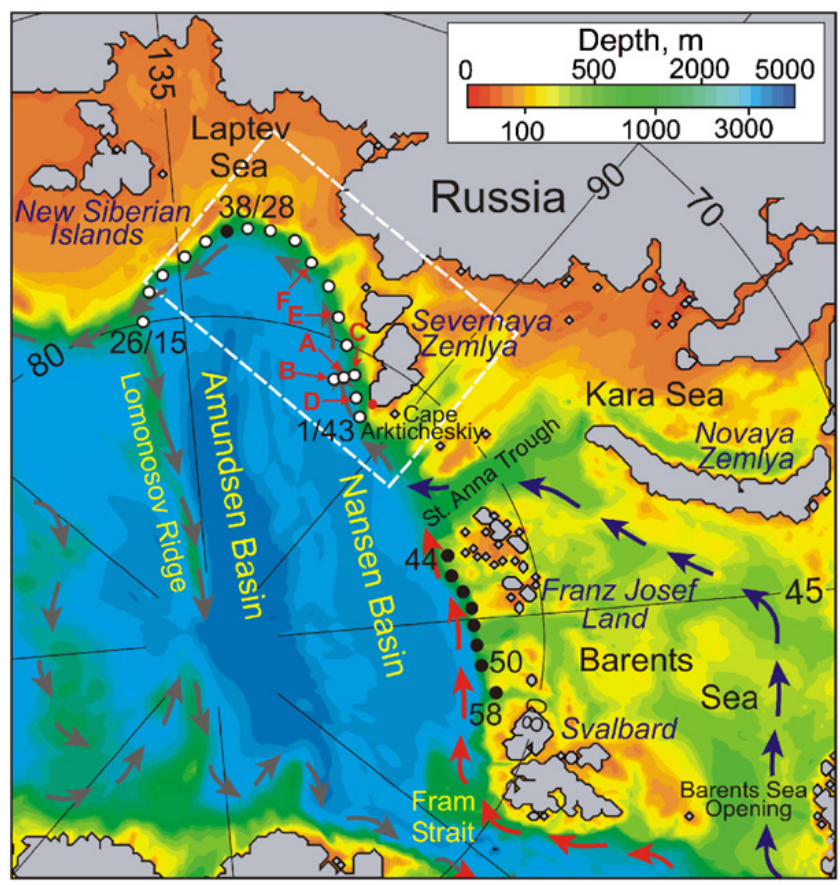

Fig. 1. A map of the Arctic Ocean. Arrows trace the AW pathways; red and blue arrows show the Fram Strait and Barents Sea branches, respectively, of the AW inflow into the Arctic Ocean in accordance with Rudels et al. (1994). Dots mark the position of NABOS 2005 (white) and 2006 (black and white) stations. Capital letters identify those stations for which the $T-S$ diagrams are shown in Fig. 4. The dashed rectangle encloses the Laptev Sea continental margin, which is enlarged in Fig. 2. Bathymetry is adapted from the International Bathymetric Chart of the Arctic Ocean (IBCAO), 2001 version (Jakobsson et al., 2001). the FSBW layer was found in the Nansen Basin in 1990 (Quadfasel et al., 1991). Positive AW anomalies of up to $1{ }^{\circ} \mathrm{C}$ were carried along the continental margins into the Arctic Ocean interior (Carmack et al., 1995; Swift et al., 1997; Woodgate et al., 2001; Schauer et al., 2002b). Polyakov et al. (2004) found that the 1990s maximum fits well with a recurring pattern of multidecadal AW variability that occurs over a time scale of 50-80 years. Since the late 1990s, AW temperature has shown a new tendency to increase (Schauer et al., 2004; Polyakov et al., 2005; Dmitrenko et al., 2008a). This new, continuing warming event has been attributed to downstream propagation of the AW warm anomaly first recorded in the Fram Strait in 1999 (Schauer et al., 2004; Polyakov et al., 2005) and further traced in the northern Laptev Sea at the beginning of 2004 (Polyakov et al., 2005; Dmitrenko et al., 2008a). While the FSBW warming of the 2000s is well documented over the Siberian margin, the tendency of the BSWB remains poorly known.

This paper addresses the issue of interannual (1995, and 2005-2006) variability of the BSBW layer in the western Laptev Sea, the area located directly downstream of the FSBW and BSBW confluence, using shipboard conductivity, temperature, and depth (CTD), dissolved oxygen (DO), and stable oxygen isotope data. We demonstrate that the BSBW has tended to cool, while since the mid-2000s the FSBW has clearly exhibited a contrary tendency to warm (Polyakov et al., 2005; Dmitrenko et al., 2008a). More specifically, our study focuses on the modification of the BSBW during its translation through the Barents and northern Kara seas due to sea-ice and air-sea interaction events. The paper is structured as follows: Section 2 is a brief description of data. Through the analysis of 2005-2006 observational data, Section 3.1 reveals the characteristic difference in the BSBW properties in 2005 and 2006. Section 3.2 compares the CTD data from 2005 to 2006 with both the data from 1995, and a long-term mean BSBW hydrography compiled using the entire CTD historical data set available from this region. Section 3.3 examines the difference in BSBW stable oxygen isotope data sampled in 1995 and 2006, which can be applied to the interpretation of the 2005-2006 difference, even though stable oxygen isotope data from deeper than $500 \mathrm{~m}$ are not available for 2005 . Section 4 puts our findings into the context of upstream sea-ice and atmospheric conditions over the Barents and northern Kara seas to determine possible causes of BSBW modification from 2005 to 2006. Section 5 summarizes our conclusions and points out limitations in our analysis.

\section{Data}

The data used in this study were collected from CTD surveys over the continental slope of the Eurasian Arctic in 2005 and 2006. In 2006 the along-slope transect occupied the continental slope approximately following the $1500 \mathrm{~m}$ depth contour between $31^{\circ} \mathrm{E}$ and $142^{\circ} \mathrm{E}$, and the eastern portion of this transect, between $97^{\circ} \mathrm{E}$ and $142^{\circ} \mathrm{E}$, was also sampled in 2005 (Fig. 1). The cross-slope 


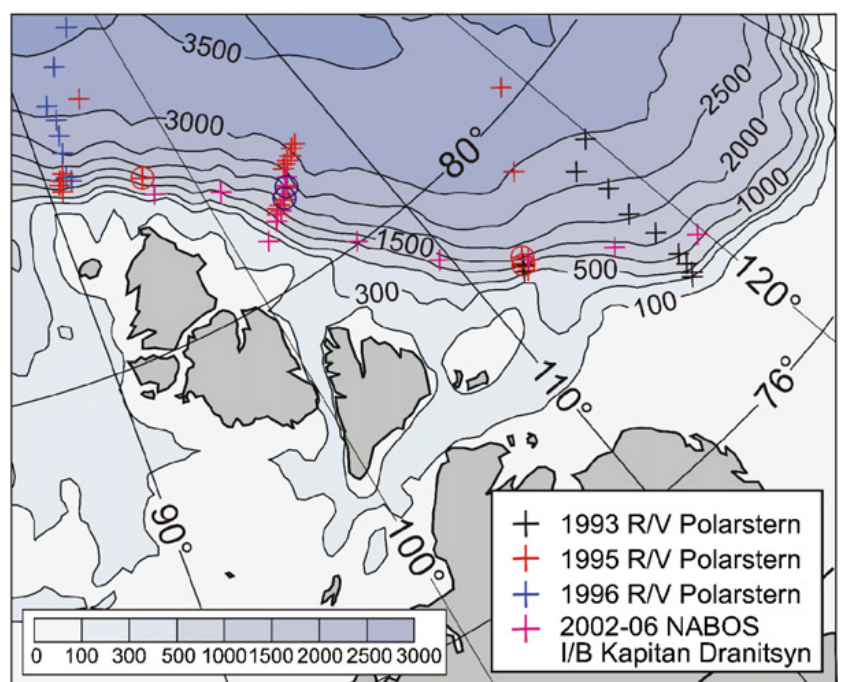

Fig. 2. A map of the Laptev Sea continental margin. Crosses mark the CTD stations occupied in August-September of 1993-2006 between $90^{\circ}$ and $120^{\circ}$ E. Circled crosses show 1995 CTD profiles used to draw the $T-S$ plots in Fig. 5A. Blue circles mark 1995 stations shown in Fig. 6A. Bathymetry is adapted from the International Bathymetric Chart of the Arctic Ocean (IBCAO), 2001 version (Jakobsson et al., 2001).

transect at approximately $105^{\circ} \mathrm{E}$ was also carried out at the same positions in 2005 and 2006 (Fig. 2). The CTD sensors were calibrated by the manufacturer (Sea-Bird Electronics Inc.) before each cruise. These data were complemented by oceanographic stations occupied between $90^{\circ} \mathrm{E}$ and $120^{\circ} \mathrm{E}$ in August-September of 1993,1995 , and 1996 during the ARKIX-4 (1993), ARKXI-1 (1995), and ARKXII (1996) cruises of the R.V. Polarstern (Schauer et al., 2002b) (Fig. 2). According to the manufacturers' estimates, the individual temperature and conductivity measurements are accurate to $\pm 0.005^{\circ} \mathrm{C}$ and $\pm 0.0005 \mathrm{~S} / \mathrm{m}$, respectively, for the SBE-19plus (Kapitan Dranitsyn), and $\pm 0.003{ }^{\circ} \mathrm{C}$ and $0.0005 \mathrm{~S} / \mathrm{m}$ for the modified Neil Brown Mark III b (Polarstern). Several stations in 2006 were taken by the Lockheed Martin Sippican Expendable Bathythermographs (XBTs) with an accuracy of $\pm 0.05^{\circ} \mathrm{C}$.

DO was sampled by a 24-bottle carousel down to $1000 \mathrm{~m}$ (see Fig. 3 for sampling levels) and determined by titration according to the Winkler method (Strickland and Parson, 1972). The individual DO measurements are accurate to $\pm 0.5 \mu \mathrm{mol} / \mathrm{kg}$.

For the region between $90^{\circ} \mathrm{E}$ and $120^{\circ} \mathrm{E}$, stable oxygen isotope $\left(\delta^{18} \mathrm{O}\right)$ data are available from 1995 and 2006 only. In $2005, \delta^{18} \mathrm{O}$ samples were taken down to $500 \mathrm{~m}$, and the BSWB was not captured at all. Oxygen isotopes were analyzed using the $\mathrm{CO}_{2}$-water isotope equilibration technique. Data collected in 2006 were analyzed at the Leibniz Laboratory on $0.5 \mathrm{ml}$ sub-samples using a Finnigan

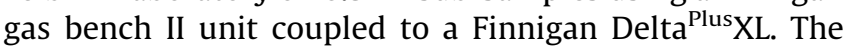
${ }^{18} \mathrm{O} /{ }^{16} \mathrm{O}$ ratio $(R)$ is given versus the Vienna Standard Mean Ocean Water (VSMOW) standard in the usual $\delta$-notation (Craig, 1961): $\delta^{18} \mathrm{O}_{\text {sample }}=\left(R_{\text {sample }} / R_{\text {standard }}-1\right) 1000$. The measurement precision for $\delta^{18} \mathrm{O}$ analysis is $\pm 0.03 \%$ or better. Additional $\delta^{18} \mathrm{O}$ and salinity data are available from the 1995 R.V. Polarstern expedition ARKXI-1 (http:// data.giss.nasa.gov/o18data/; Schmidt et al., 1999) with a measurement precision for the $\delta^{18} \mathrm{O}$ analysis of $\pm 0.03 \%$ or better (Frank, 1996).

Monthly averaged sea level pressure (SLP), surface air temperature (SAT), and wind data over the Barents and northern Kara seas were derived from the National Center for Environmental Prediction/National Center for Atmospheric Research (NCEP/NCAR) reanalysis data set. The horizontal resolution of the NCEP-derived data is $2.5^{\circ}$ of latitude. Sea-ice concentration data are from the "Nimbus-7 Scanning Multichannel Microwave Radiometer (SMMR) and Defense Meteorological Satellite Program (DMSP) Special Sensor Microwave/Imager (SSM/I) Passive Microwave Data" dataset (Cavalieri et al., 2006), which has a grid cell size of $25 \times 25 \mathrm{~km}$. The sea-ice and atmospheric monthly mean data were collected and averaged for 1979-2007 over the Barents and northern Kara seas: between $15^{\circ} \mathrm{E}$ and $52^{\circ} \mathrm{E}$ longitude and $71^{\circ} \mathrm{N}$ and $81^{\circ} \mathrm{N}$ latitude, and north of Novaya Zemlya to $81^{\circ} \mathrm{N}$ latitude further east between $52^{\circ} \mathrm{E}$ and $70^{\circ} \mathrm{E}$ longitude.

\section{Results}

\subsection{Results from 2005 to 2006 along-slope observations}

Here we document the 2005-2006 differences in FSBW and BSBW properties over the Laptev Sea continental slope $\left(97-142^{\circ} \mathrm{E}\right)$ through analysis of CTD and DO observational data. For 2006, we extend our analysis of the FSBW further westward to $31^{\circ} \mathrm{E}$ following the along-slope section (Fig. 3, left portion of left panel). First, we examine temperature, DO, and potential density on along-slope sections from 2005 to 2006 with a primary focus on changes in the FSBW and the BSBW characteristics. Second, we define the range of 2006 BSBW core temperature, salinity, density, and DO concentration relative to 2005 from the temperature-salinity $(T-S)$ diagrams derived from CTD profiles taken over the western Laptev Sea continental slope in the same positions in September 2005 and 2006.

The vertical distributions of temperature, DO, and density over the along-slope sections taken in 2005 and 2006 exhibit the main patterns of AW inflow into the Arctic Ocean. Over the western Eurasian Basin the FSBW core temperature sampled in 2006 exhibits substantial variability, gradually decreasing along-slope from $4.5^{\circ} \mathrm{C}$ between Svalbard and Franz Josef Land, to $2.25^{\circ} \mathrm{C}$ to the east of Cape Arkticheskiy in the western Laptev Sea, and $1.5^{\circ} \mathrm{C}$ over the Eurasian flank of the Lomonosov Ridge (Fig. 3A, left). This rate of decrease exceeds the long-term mean reported by Polyakov et al. (2004) and Dmitrenko et al. (2008a). The FSBW core sampled in 2005 exhibits lower temperatures gradually decreasing from $2{ }^{\circ} \mathrm{C}$ in the western Laptev Sea to 1.5 and $1.0^{\circ} \mathrm{C}$ in the central and eastern Laptev Sea, respectively (Fig. 3A, right). As it cools, the FSBW core deepens along-margin, from approximately $130 \mathrm{~m}$ northeast of Svalbard to $270 \mathrm{~m}$ near Cape Arkticheskiy, and $300 \mathrm{~m}$ north of the New Siberian Islands in both 2005 and 2006 (Fig. 3A). In 2006, the FSBW core DO concentration slightly varies along-slope from 300 to $310 \mu \mathrm{mol} / \mathrm{kg}$ while the DO saturation decreases from $91 \%$ 


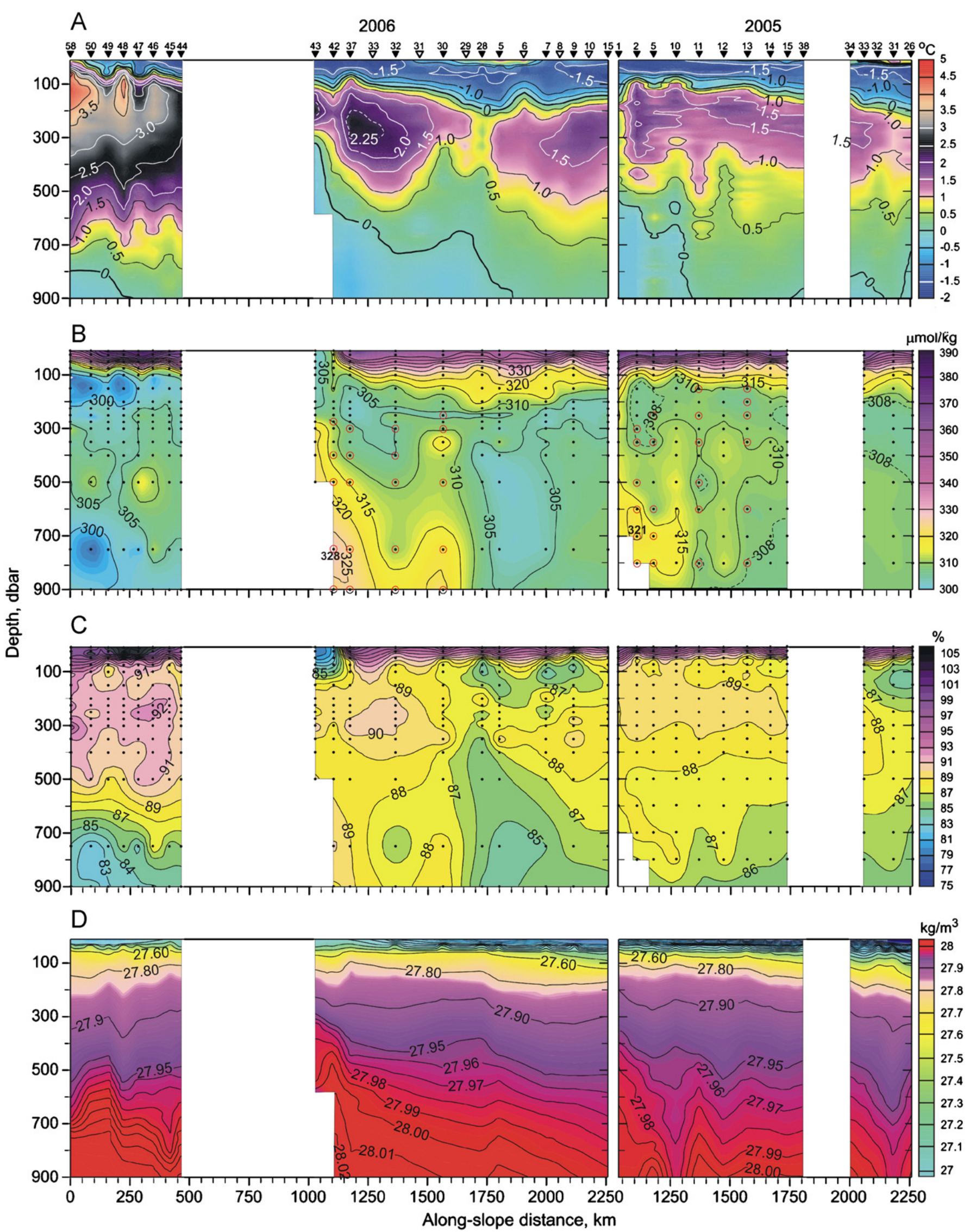

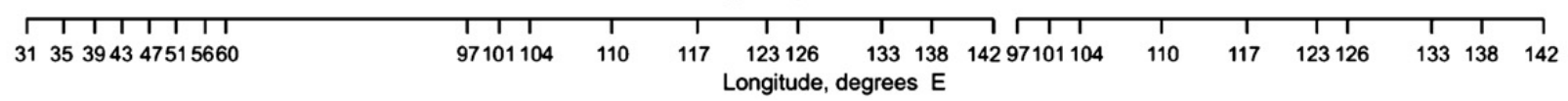


to $92 \%$ near Svalbard, to $90 \%$ near Cape Arcticheskiy, to $88 \%$ north of the New Siberian Islands (Figs. 3B and C, left panels). The 2005 FSBW core demonstrates relatively stable DO concentration values of about $308 \mu \mathrm{mol} / \mathrm{kg}$ with DO saturation gradually decreasing along-slope from $89 \%$ to $87 \%$ (Figs. 3B and $\mathrm{C}$, right panels). The along-slope variability in FSBW temperature, salinity, and DO from $106^{\circ}$ to $112^{\circ} \mathrm{E}\left(2005\right.$, Fig. 3, right) and $119^{\circ}$ to $126^{\circ} \mathrm{E}(2006$, Fig. 3, left) is likely attributable to the cross-slope displacement of the AW boundary current jet (Dmitrenko et al., 2008a).

The along-slope section taken in 2005-2006 confirms the FSBW and the BSBW circulation scheme proposed by Rudels et al. (1994) showing the confluence of both AW branches over the northern Kara Sea (Fig. 1). Usually, downstream from the confluence with the FSBW, the BSBW demonstrates a clear thermohaline signature with temperature and salinity intermediate minima beneath the FSBW layer. The $0{ }^{\circ} \mathrm{C}$ isotherm over the western Laptev Sea is uplifted relative to the eastern Laptev Sea by the cooler BSBW layer beneath (Fig. 3A). Hence the BSBW inflow displaces the ambient water both upward and downward. The BSBW layer is well traced between $97^{\circ}$ and $108^{\circ} \mathrm{E}$, the area located directly downstream of the FSBW and BSBW confluence in the northern Kara Sea (Fig. 1), in the 500-900 $\mathrm{m}$ layer by higher DO concentrations $(\sim 315-321 \mu \mathrm{mol} / \mathrm{kg}$ in 2005-Fig. 3B, right, and $\sim 315-328 \mu \mathrm{mol} / \mathrm{kg}$ in 2006-Fig. 3B, left). These BSBW DO concentrations exceed those in the FSBW layer by $8-15 \mu \mathrm{mol} / \mathrm{kg}$ (Fig. 3B and Fig. 4). In fact, the BSBW thermohaline signature is also evident in $T-S$ diagrams derived from CTD casts taken over the western Laptev Sea (Fig. 4). While in 2006 the BSBW is traced along-slope to $120^{\circ} \mathrm{E}$, in 2005 it remains clearly recognizable only to $108^{\circ} \mathrm{E}$ (compare 2005 and $2006 \mathrm{~T}-\mathrm{S}$ curves and DO in Figs. 4E and F). Further eastwards temperature, salinity, or DO concentration data do not provide evidence of the BSBW signature (Fig. 3); this is likely due to vertical and lateral mixing of the BSBW with surrounding ambient water (Schauer et al., 2002b). The 5-month mean (September 2004-February 2005) T-S diagram derived from daily casts of the moored CTD profiler deployed on the central Laptev Sea continental slope at $\sim 126^{\circ} \mathrm{E}$ also exhibits no clear $T-S$ intermediate minima beneath the FSBW, indicating no BSBW presence (Dmitrenko et al., 2008b). Note, however, that the BSBW still exhibits a traceable signature in the Canada basin (McLaughlin et al., 2002; Woodgate et al., 2007) that underlines the importance of temporal variability of the BSBW inflow into the Arctic Ocean.

More precise evidence of the 2005-2006 differences in FSBW and BSBW properties comes from comparing $T-S$ diagrams derived from CTD profiles taken in the western Laptev Sea in 2005 and 2006. The difference between 2005 and 2006 AW properties is striking. From 2005 to
2006, the FSBW temperature and salinity increased by $0.7^{\circ} \mathrm{C}$ and 0.05 , respectively (Fig. $3 \mathrm{~A}$, and Figs. $4 \mathrm{~A}-\mathrm{C}$, and $\mathrm{E}$ ), but almost the same potential density (sigma-0) of about $27.90-27.92 \mathrm{~kg} / \mathrm{m}^{3}$ was maintained (Figs. 3D and 4). The DO saturation of the FSBW exhibits no substantial variations ( $\sim 89-90 \%$, Figs. $3 C$ and 4$)$. The $T-S$ diagrams shown in Figs. 4D and F demonstrate no FSBW core temperature increase from 2005 to 2006 that might be attributed to cross-slope shifting of the FSBW boundary current jet in 2006. The range of the 2005-2006 FSBW core temperature variability here is within the noise level produced by cross-slope shifting of the AW jet and reported for this region by Dmitrenko et al. (2008a) to be $\sim 0.3-0.4^{\circ} \mathrm{C}$.

On the $T-S$ plane, the BSBW usually demonstrates a clear thermohaline signature (for example, see the intermediate temperature and salinity minima from 2005, curves marked with black in Figs. 4B and C). However, we also use the DO intermediate maxima from the $500-1000 \mathrm{~m}$ layer as a tracer of the BSBW core in those cases for which the BSBW thermohaline signature is not well defined (for example, see the 2006 curve in Fig. 4E), or multiple cooler and fresher intrusions are observed (the 2005 curve in Fig. 4B). Our data clearly show that compared with FSBW, the BSBW core demonstrates a contrary tendency to cool by $0.02-0.40{ }^{\circ} \mathrm{C}$, while salinity tends to increase by $0.02-0.05$ (Figs. 4A-D), as for the FSBW. On average, the 2006 BSBW DO concentration exceeds that of 2005 by $7-8 \mu \mathrm{mol} / \mathrm{kg}$, and by $\sim 2 \%$ of saturation (Fig. 4). The potential density of the BSBW core also exhibits highly significant changes. In 2006, the BSBW core was denser than in 2005 by $\sim 0.04 \mathrm{~kg} / \mathrm{m}^{3}$ (Figs. 4A, C, and D) $-0.06 \mathrm{~kg} / \mathrm{m}^{3}$ (Fig. 4B).

\subsection{Comparing the 2005-2006 measurements with 1995 and a regional mean}

Our general goal here is to evaluate the significance of changes observed from 2005 to 2006 by comparing the 2005 to 2006 CTD measurements with a regional longterm mean. Because of the coarse vertical resolution of the historical data, particularly in the vicinity of the BSBW core, the representative temperature, salinity, density, and depth of the BSBW core can be accurately estimated only from the CTD measurements that have been made in this region since the early 1990s. Therefore, our computation of mean conditions covers a limited period of CTD observations from 1993 to 2006. We also extend our analysis to the 1995 CTD data to provide a hydrographic background for interpreting stable oxygen isotope data from 2006 relative to 1995 .

First, we compare the FSBW and BSBW potential densities derived from the 2005 and 2006 CTD profiles taken over the western Laptev Sea continental slope with the mean FSBW and BSBW potential densities before

Fig. 3. Ten meters binned along-slope sections taken in September 2006 (left) and 2005 (right) along the Eurasian continental slope: (A) temperature ( ${ }^{\circ} \mathrm{C}$ ), (B) dissolved oxygen ( $\mu \mathrm{mol} / \mathrm{kg}$ ), (C) dissolved oxygen saturation (\%), and (D) potential density ( $\operatorname{sigma}-0, \mathrm{~kg} / \mathrm{m}^{3}$ ). Blank areas on the left represent missing data through the Santa Anna Trough (see Fig. 1). Dots mark the water sampling levels. Red circles indicate those levels from which the dissolved oxygen values are shown in Fig. 4. Black and white triangles with station numbers on the top show positions of CTD and XBT stations, respectively. The western end of the 2005 section lies at station 43 in 2006, at the eastern end of the data gap. 


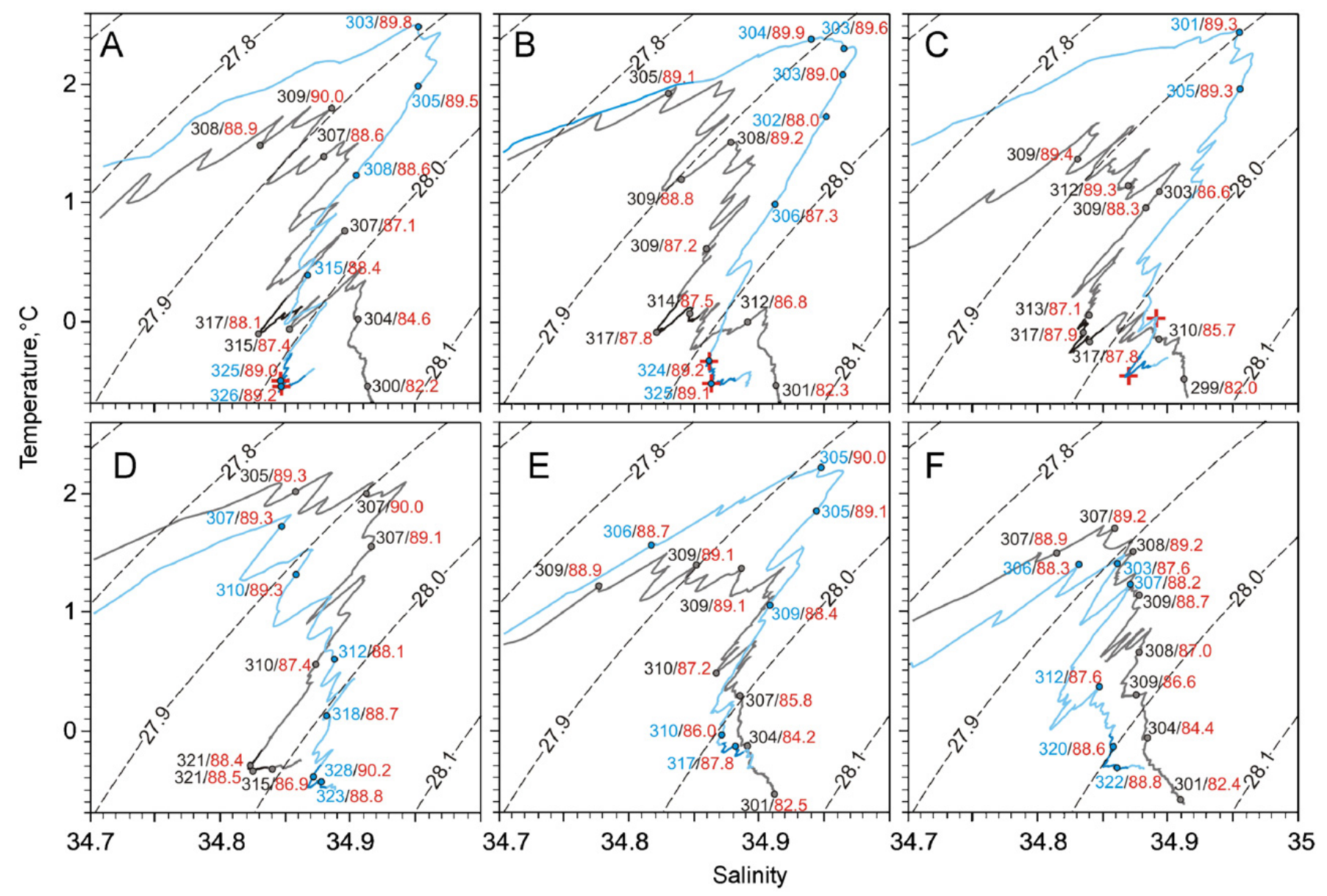

Fig. 4. The T-S diagrams for CTD profiles taken through the FSBW and BSBW cores off the western Laptev Sea continental shelf break in 2005 and 2006. Profiles D, A, E and F lie along the stream from northwest to southeast, and B, A and C across the stream from northeast to southwest (see Fig. 1 for station positions). Each panel contains two curves derived from the CTD profiles taken in the same position in September 2005 (gray line) and 2006 (blue line). Maximal temperature and salinity values within sigma-0 of $27.85-27.95 \mathrm{~kg} / \mathrm{m}^{3}$ define the FSBW core. Minimal temperature and salinity, and maximal DO values within $27.95-28.05 \mathrm{~kg} / \mathrm{m}^{3}$ of sigma-0 identify the BSBW core marked with black and deep blue lines for 2005 and 2006 , respectively. Dashed lines are sigma-0 isopycnals in $\mathrm{kg} / \mathrm{m}^{3}$. The DO concentration $(\mu \mathrm{mol} / \mathrm{kg}$ ) for 2005 and 2006 is depicted by blue and gray numbers, respectively. The DO saturation (\%) is shown by red numbers. The extremes in T, S, and DO may not coincide because of the discrete water sampling levels for the DO analysis (see Fig. 3 for water sampling levels). Red crosses on the top panels show $\delta^{18} \mathrm{O}$ sampling levels.

extending our analysis to a comparison with 1995 data. The mean vertical $T-S$ profiles were computed using 45 individual CTD profiles measured off the continental shelf break between $90^{\circ}$ and $120^{\circ} \mathrm{E}$ in August-September 1993-2006 (Fig. 2). T-S profiles with the BSBW signature were averaged over the potential isopycnals. In this area the BSBW jet is relatively narrow and usually is found shifted on-slope, while the FSBW jet is shifted more offslope (for example see Schauer et al., 2002b). Therefore CTD profiles taken over the lower continental slope usually do not exhibit the BSBW signature. The $T-S$ diagram for the mean profile reveals a mean FSBW sigma-0 of about $27.92 \mathrm{~kg} / \mathrm{m}^{3}$ (red dashed line in Fig. 5), while the BSBW exhibits a mean sigma-0 of about $27.97 \mathrm{~kg} / \mathrm{m}^{3}$ (blue dashed line in Fig. 5). The yellow shading in Fig. 5 indicates \pm one standard deviation calculated along isopycnals. Note that we overestimate the FSBW core temperature standard deviation by limiting the observational period to 1993-2006, the period during which the AW temperature demonstrated the most spectacular variability of the entire period of observations since the beginning of the 1900s (Polyakov et al., 2004). The pre-1990s FSBW core temperature standard deviation from this region was reported by Dmitrenko et al. (2008a) to be about $30 \%$ smaller. In fact, our mean sigma-0 estimations are consistent with those reported from the Nansen, Amundsen, and Makarov basins for the early 1990s of 27.90 and $28.00 \mathrm{~kg} / \mathrm{m}^{3}$ for the FSBW and BSBW, respectively (McLaughlin et al., 2002).

The $T-S$ characteristics and potential densities for the FSBW and the BSBW cores sampled in 2005 correspond well to the FSBW and the BSBW means (Fig. 5B). Basically, the $T-S$ curves derived from the individual 2005 CTD profiles do not exceed one standard deviation from the mean within the range of temperature and salinity corresponding to the approximate depth of the FSBW and BSBW, demonstrating relatively low spatial variability (Fig. 5B). The 2006 FSBW core density is reasonably consistent with mean density, while both FSBW core temperature and salinity substantially exceed standard deviation, tending towards much warmer and saltier conditions (Fig. 5C). We argue that this FSBW warming 

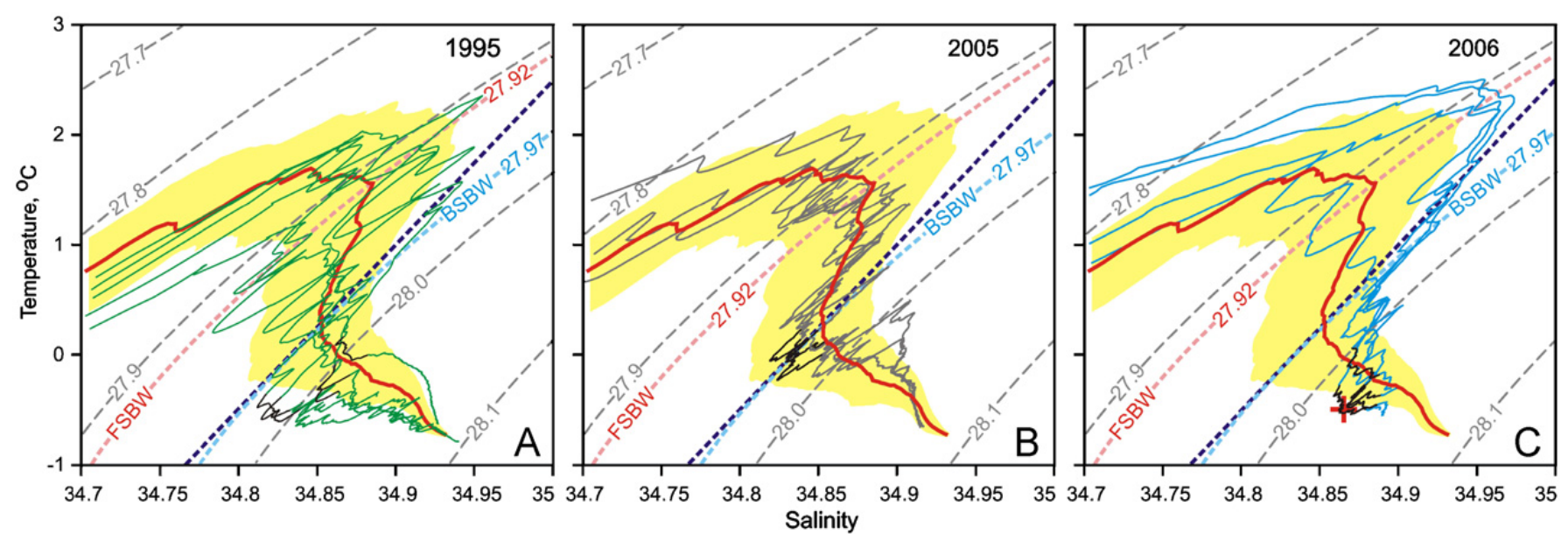

Fig. 5. In all panels, the red solid line shows a $T-S$ diagram of the mean of all shipboard CTD profiles taken between $90^{\circ}$ and $120^{\circ} \mathrm{E}$ from 1993 to 2006 which exhibit the BSBW signature; the yellow shading indicates \pm one standard deviation of the mean. The dashed lines are sigma- 0 isopycnals in $\mathrm{kg} / \mathrm{m}^{3}$. Pink and blue dashed lines identify the mean sigma- 0 of the FSBW and BSBW cores, respectively. Deep blue dashed line shows the long-term mean $T-S$ diagram for the BSBW in the Barents Sea adapted from Smolyar and Adrov (2003). The green, gray, and blue lines are $T-S$ diagrams for CTD profiles taken through the BSBW core over the western Laptev Sea in 1995 (A), 2005 (B) and 2006 (C), respectively. The portion of the T-S diagram that defines the BSBW core is shown by black. The mean $T-S$ characteristic of the BSBW observed in 2007 from the R.V. Akademik Fedorov is shown in (C) by a red cross according to I. Ashik (pers. commun., 2007).

is due to a new pulse of the warm AW anomaly propagating downstream that was first captured over the continental slope of the central Laptev Sea in 2004 (Polyakov et al., 2005; Dmitrenko et al., 2008a). The 2006 BSBW temperature and salinity are outside of the range of one standard deviation of the mean, tending towards much cooler, saltier, and denser conditions (Fig. 5C). Throughout almost the entire range of temperature and salinity the $2006 \mathrm{~T}-\mathrm{S}$ curves are outside of the range of one standard deviation from the mean, but individual $T-S$ curves derived from the spatially distributed observations exhibit relatively low spatial variability in the $T-S$ plane (Fig. 5C) with one exception also shown in Fig. 4D.

Now we extend our analysis of 2005-2006 interannual variability to the 1995 data from the western Laptev Sea continental slope (see Fig. 2 for 1995 station positions). Fig. 5A shows the $T-S$ diagrams derived from the CTD profiles taken in 1995 through the BSBW core in positions reasonably close to the locations of the 2005-2006 stations, which are depicted with circled crosses in Fig. 2. The $1995 T-S$ curves exhibit much higher spatial variability than those from 2005 to 2006; however, in most cases they remain within a range of one standard deviation of the mean. The FSBW core temperature and salinity are above the means by $\sim 0.5-1.0^{\circ} \mathrm{C}$ and $\sim 0.02$; this is directly linked to the AW warming of the 1990s (Quadfasel et al., 1991; Carmack et al., 1995; Woodgate et al., 2001; Schauer et al., 2002b; Karcher et al., 2003; Polyakov et al., 2004). Schauer et al. (2002b) reported that in 1995 the temperature of the off-slope-shifted FSBW was about $2.6^{\circ} \mathrm{C}$. The $2.4^{\circ} \mathrm{C}$ FSBW core was also captured by the 1995 CTD profile taken through the BSBW layer at the upper continental slope at $\sim 113^{\circ} \mathrm{E}$ (Figs. 2 and $5 \mathrm{~A}$ ). These values are about the same magnitude as those recorded in 2006 (Fig. 4C). The 1995 BSBW core temperature and salinity vary substantially from 0 to $-0.65{ }^{\circ} \mathrm{C}$ and from 38.81 to 34.87 , respectively (Fig. 5A). Consequently, the potential density of 1995 BSBW exhibits substantial spatial variability above the level of the mean by $0.01-0.04 \mathrm{~kg} / \mathrm{m}^{3}$ (Fig. 5A). The BSBW core temperature sampled in 1995 at about $104^{\circ} \mathrm{E}$ (Fig. 6A) is almost the same as that of 2006 (Fig. 6B), while the 1995 core is fresher by $\sim 0.05$, with density diminished by $\sim 0.02-0.03 \mathrm{~kg} / \mathrm{m}^{3}$.

The BSBW core thermohaline properties averaged over the western Laptev Sea are summarized in Table 1. Among 1995,2005 , and 2006, the highest BSBW core density was recorded in 2006, substantially exceeding the 1993-2006 mean by $\sim 0.05 \mathrm{~kg} / \mathrm{m}^{3}$ because of lower temperature (by $\sim 0.9^{\circ} \mathrm{C}$ ) and higher salinity (by $\sim 0.01$ ). The 2005 dataset demonstrates conditions that better correspond to the mean density, with temperature and salinity slightly below the mean (Table 1). In terms of density, the BSBW core of 1995 is found between 2005 and 2006 values, but relatively high spatial variability does not allow clear thermohaline attribution of the observed tendency. In contrast to the 2005-2006 FSBW warming, the BSBW clearly exhibits a cooling tendency. This BSBW cooling tendency also differs from the AW warming of the 1990s when almost the entire intermediate water column (both FSBW and BSBW) became warmer. Observations reveal that this change was most pronounced in the upper layer dominated by the FSBW and less pronounced at greater depth, where the BSBW contribution is greater (Schauer et al., 2002b). Modeling by Zhang et al. (1998) attributes the warming of the 1990s to warm water inflow through the Barents Sea. However, McLaughlin et al. (2002) reported that from 1993 to 1995 the FSBW and the BSBW exhibited contrary tendencies: the FSBW became fresher and colder, while the BSBW became fresher, warmer, and better ventilated.

Comparison of the 1995, 2005, and 2006 BSBW core $T-S$ properties to the Barents Sea (upstream) long-term mean by Smolyar and Adrov (2003) reveals almost the same patterns as the downstream long-term mean: within the BSBW core temperature and salinity range of 

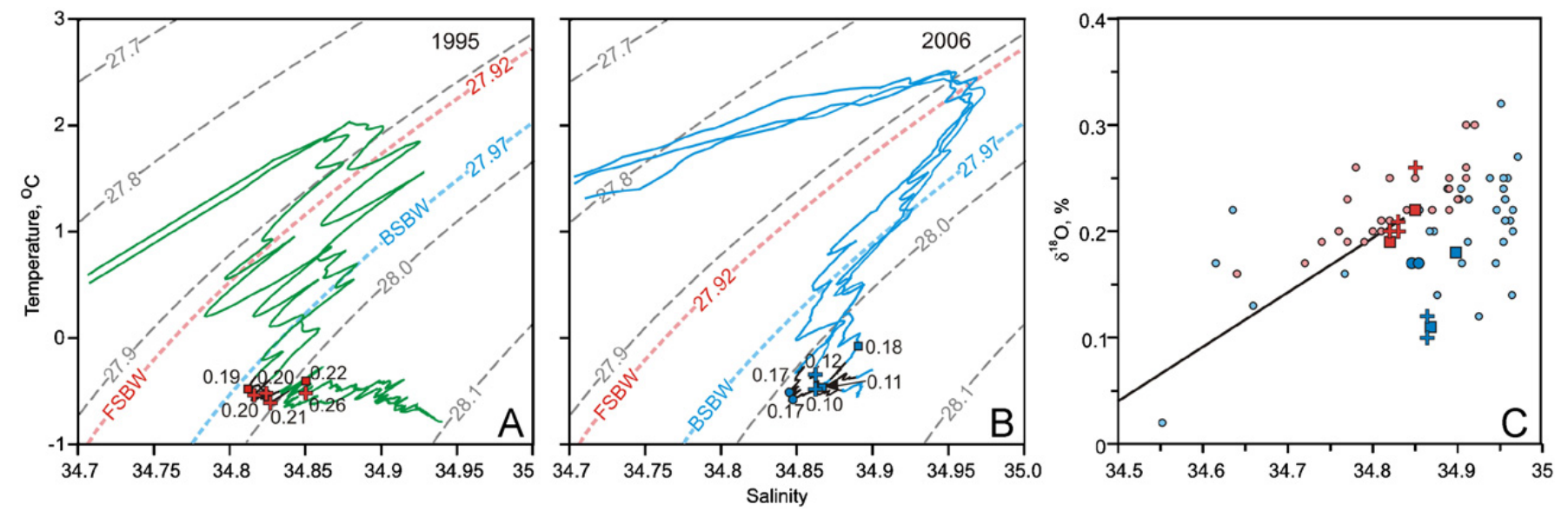

Fig. 6. The green and blue lines are $T-S$ diagrams for the CTD profiles taken through the BSBW core over the western Laptev Sea in 1995 (A) and 2006 (B). The portion of the $T-S$ diagram that defines the BSBW core is shown in black. The numbered symbols show $\delta^{18} \mathrm{O}$ values from Table 2 . Dashed lines are sigma-0 isopycnals in $\mathrm{kg} / \mathrm{m}^{3}$. Panel (C) shows a plot of $\delta^{18} \mathrm{O}$ versus salinity for data with salinities above 34.5 . The black line is the direct mixing line between the average value of BSBW in $1995\left(0.21 \%\right.$ in $\delta^{18} \mathrm{O}$ and 34.83 in salinity) and the value representing average Arctic river runoff $\left(-18 \%\right.$ in $\delta^{18} \mathrm{O}$ and 0 in salinity) as used within the mass balance calculations. For further explanation see text. Data points from 1995 and 2006 are shown by red and blue symbols, respectively. On all panels the data points depicted with enlarged dots, crosses, and rectangles are labeled according to their geographical and vertical distribution through the BSBW core as shown on the panels (A) and (B), Figs. 1-3 (top), and Table 2. Small dots on the right depict all other points, sampled outside the BSBW core.

\section{Table 1}

The BSBW core temperature, salinity, and sigma-0 averaged over the western Laptev Sea: the 1993-2006, 1995, 2005, 2006, and 2007 mean \pm one standard deviation.

\begin{tabular}{|c|c|c|c|}
\hline \multirow[t]{2}{*}{ Year } & \multicolumn{3}{|c|}{ BSBW core properties } \\
\hline & Temperature $\left({ }^{\circ} \mathrm{C}\right)$ & Salinity & Sigma-0 $\left(\mathrm{kg} / \mathrm{m}^{3}\right)$ \\
\hline 1993-2006 mean & $0.25 \pm 0.30$ & $34.851 \pm 0.030$ & $27.97 \pm 0.01$ \\
\hline 1995 & $-0.36 \pm 0.23$ & $34.839 \pm 0.017$ & $27.99 \pm 0.01$ \\
\hline 2005 & $-0.21 \pm 0.11$ & $34.824 \pm 0.004$ & $27.98 \pm 0.01$ \\
\hline 2006 & $-0.62 \pm 0.29$ & $34.861 \pm 0.011$ & $28.02 \pm 0.02$ \\
\hline 2007 & $-0.52 \pm 0.02$ & $34.870 \pm 0.010$ & $28.03 \pm 0.01$ \\
\hline
\end{tabular}

Data for 2007 are shown according to I. Ashik (pers. commun., 2007).

$\sim 0 \pm 0.5$ and $\sim 34.85 \pm 0.05$, respectively, the downstream mean BSBW core sigma-0 isopycnal of $\sim 27.97 \mathrm{~kg} / \mathrm{m}^{3}$ (blue dashed line in Fig. 5) roughly coincides with the BSBW upstream mean $T-S$ diagram (deep-blue dashed line in Fig. 5). However, the upstream BSBW demonstrates strong spatial, seasonal, and interannual variability (see Table 1 in Smolyar and Adrov, 2003).

The CTD survey carried out over the western Laptev Sea continental slope in August 2007, in almost the same positions as in 2005-2006, revealed the BSBW core at 900-1000 m depth with temperature, salinity, and density of about $-0.52 \pm 0.02{ }^{\circ} \mathrm{C}, 34.87 \pm 0.01$, and $28.03 \pm 0.01 \mathrm{~kg} / \mathrm{m}^{3}$, respectively (I. Ashik, pers. commun., 2007). The 2007 observations are consistent with our 2006 results (Table 1 and Fig. 5C), confirming the 2005-2006 tendency of the BSBW to cool.

\subsection{Results from combined stable oxygen isotope and salinity data from 1995 and 2006}

Here the BSBW stable oxygen isotope values $\left(\delta^{18} \mathrm{O}\right)$ in 2006 are compared with 1995 values and the relative contribution of river water and sea-ice meltwater is determined. The 2005 oxygen isotope data sampled down to $500 \mathrm{~m}$ did not capture the BSBW layer; therefore, the 1995 BSBW core data sampled over the same area were chosen as a reference point for the 2006 BSBW stable oxygen isotope data.

An interpretation of $\delta^{18} \mathrm{O}$ in terms of a water mass analysis must account for the corresponding salinity relative to a reference point: discrepancies between salinity and $\delta^{18} \mathrm{O}$ variations can then be used to quantify the relative proportions of the contributing water masses. Arctic river water has a pronounced $\delta^{18} \mathrm{O}$ of about $-16 \%$ to $-20 \%$ (Ekwurzel et al., 2001; Bauch et al., 2005), while the $\delta^{18} \mathrm{O}$ value of Atlantic-derived Arctic Ocean water is about $0.3 \%$ at about 34.92 salinity (Bauch et al., 1995). An admixture of river water affects both the $\delta^{18} \mathrm{O}$ and salinity balance of water mass. The impact of sea-ice on $\delta^{18} \mathrm{O}$ is relatively small with a fractionation factor of 1.0026 (Melling and Moore, 1995), and salinity is primarily affected. Therefore the $\delta^{18} \mathrm{O}$ composition of the water in combination with salinity is a good measure to distinguish and quantify the amount of river runoff and sea-ice meltwater within water mass.

The mean $1995 \mathrm{BSBW}$ core $\delta^{18} \mathrm{O}$ value is $0.21 \%$ at a mean salinity of 34.83 (Fig. 6). The average $\delta^{18} \mathrm{O}$ value is well defined by two profiles with a total of six oxygen isotope analyses within the BSBW (Fig. 6A), and the standard deviation of $\pm 0.014 \%$ is well within the range of the $\delta^{18} \mathrm{O}$ measurement error of $\pm 0.03 \%$. The mean salinity sampled for $\delta^{18} \mathrm{O}$ is 34.83 , within the 1995 BSBW CTD data range of 34.81-34.87. In 2006, observed BSBW $\delta^{18} \mathrm{O}$ values are lower by $0.04-0.11 \%$ compared with 1995 data (Figs. 6B and C), while 2006 salinities are higher by 0.03 compared with 1995 values.

By applying a mass-balance calculation to the salinity and $\delta^{18} \mathrm{O}$ data the fractions of sea-ice meltwater and river water relative to a marine source can be calculated. Several studies have applied this concept to Arctic Ocean 
halocline waters (e.g. Östlund and Hut, 1984; Bauch et al., 1995; Macdonald et al., 1995; Ekwurzel et al., 2001) and also to Arctic Ocean deep and bottom waters (Bauch et al., 1995). The balance is governed by the following equations:

$f_{\text {mar }}+f_{\mathrm{r}}+f_{\mathrm{i}}=1$,

$f_{\text {mar }} \times S_{\text {mar }}+f_{\mathrm{r}} \times S_{\mathrm{r}}+f_{\mathrm{i}} \times S_{\mathrm{i}}=S_{\text {meas }}$,

$f_{\text {mar }} \times O_{\text {mar }}+f_{\mathrm{r}} \times O_{\mathrm{r}}+f_{\mathrm{i}} \times O_{\mathrm{i}}=O_{\text {meas }}$,

where $f_{\text {mar }}, f_{\mathrm{r}}$, and $f_{\mathrm{i}}$ are the fractions of marine water, river-runoff, and sea-ice meltwater in a water parcel, and $S_{\mathrm{mar}}, S_{\mathrm{r}}, S_{\mathrm{i}}, O_{\mathrm{mar}}, O_{\mathrm{r}}$, and $O_{\mathrm{i}}$ are the corresponding salinities and $\delta^{18} \mathrm{O}$ values. $S_{\text {meas and }} O_{\text {meas }}$ are the measured salinity and $\delta^{18} \mathrm{O}$ of the water samples. Specific endmember values have to be chosen for the investigated area and the purpose (Bauch et al., 2003, 2005). Within the framework of this investigation we are interested in the contribution of river water and sea-ice meltwater to the BSBW in 2006 relative to the BSBW in 1995. Therefore, average $1995 \mathrm{BSBW}$ values $\left(0.21 \%\right.$ in $\delta^{18} \mathrm{O}$ and 34.83 in salinity) are taken as marine endmember values. For the river water endmember, $-18 \%$ in $\delta^{18} \mathrm{O}$ was chosen representing average Arctic river runoff (Bauch et al., 2005; Ekwurzel et al., 2001). For sea-ice meltwater, mean values for multiyear sea-ice were taken as 4.00 in salinity and $0 \%$ in $\delta^{18} \mathrm{O}$ (Pfirman et al., 1990, 2004). Using these endmember values a contribution of $-0.7 \%$ to $-0.3 \%$ from sea-ice meltwater and $0.2-0.5 \%$ from river water to the BSBW core in 2006 relative to 1995 is obtained (see Table 2 for all values). A negative fraction of sea-ice meltwater represents the fraction of water removed for sea-ice formation, reflecting the corresponding amount of brine added to the water column. Also the fractions obtained represent net values, e.g. a negative sea-ice meltwater fraction does not imply that no sea-ice was melted, but that the effect of sea-ice formation exceeded the effect of sea-ice melting in the calculated fraction. In this special application we are comparing the relative contribution of river water and sea-ice meltwater fraction of BSBW between 2006 and 1995. Please note that the calculated fractions are therefore relative contributions and they are different in proportion for both years, when another reference point is chosen, e.g. Atlantic Water within the West Spitzbergen Current (see Aagaard and Woodgate, 2001). River water and sea-ice meltwater fractions can be detected to within $\pm 0.16 \%$, limited by the measurement precision of the $\delta^{18} \mathrm{O}$ data $(0.03 \%)$. Larger variations in terms of absolute numbers are obtained when the choice of the river water endmember within the investigated area is varied: choosing $-10 \%$, which represents Norwegian coastal rivers (e.g. Mikalsen and Sejrup, 2000), instead of $-18 \%$, which represents average Arctic river runoff, changes the calculated fractions by about $-0.2 \%$ and $0.2 \%$ for sea-ice meltwater and river water, respectively. Therefore, assuming a Norwegian coastal river contribution yields a larger calculated amount of brine and river water input than assuming the relatively low Arctic river runoff value of $-18 \%$ in $\delta^{18} \mathrm{O}$; the latter was chosen to avoid overestimating the effects of sea-ice formation. The results obtained with
Table 2

Station data with values of the BSBW at the depth of $\delta^{18} \mathrm{O}$ sampling (compare Fig. 6).

\begin{tabular}{|c|c|c|c|c|c|c|c|}
\hline Year & $\begin{array}{l}\text { Lon } \\
\left({ }^{\circ} \mathrm{E}\right)\end{array}$ & $\begin{array}{l}\text { Lat } \\
\left({ }^{\circ} \mathrm{N}\right)\end{array}$ & $\begin{array}{l}\text { Depth } \\
(\mathrm{m})\end{array}$ & $T\left({ }^{\circ} \mathrm{C}\right)$ & $S$ & $\begin{array}{l}\delta^{18} \mathrm{O} \\
(\%)\end{array}$ & fi (\%) $\mathrm{fr}(\%)$ \\
\hline \multirow[t]{6}{*}{1995} & \multirow[t]{4}{*}{103.81} & \multirow[t]{4}{*}{80.79} & 573 & -0.55 & 34.82 & 0.20 & \\
\hline & & & 643 & -0.54 & 34.83 & 0.20 & \\
\hline & & & 789 & -0.68 & 34.83 & 0.21 & \\
\hline & & & 986 & -0.63 & 34.85 & 0.26 & \\
\hline & \multirow[t]{2}{*}{104.17} & \multirow[t]{2}{*}{80.83} & 593 & -0.52 & 34.82 & 0.19 & \\
\hline & & & 691 & -0.37 & 34.85 & 0.22 & \\
\hline \multirow[t]{6}{*}{2006} & \multirow[t]{2}{*}{103.82} & \multirow[t]{2}{*}{80.79} & 750 & -0.512 & 34.846 & 0.17 & -0.260 .19 \\
\hline & & & 900 & -0.540 & 34.854 & 0.17 & -0.280 .18 \\
\hline & \multirow[t]{2}{*}{105.01} & \multirow[t]{2}{*}{80.96} & 750 & -0.336 & 34.864 & 0.12 & -0.580 .42 \\
\hline & & & 900 & -0.527 & 34.864 & 0.10 & -0.690 .51 \\
\hline & \multirow[t]{2}{*}{105.34} & \multirow[t]{2}{*}{81.04} & 750 & -0.009 & 34.898 & 0.18 & -0.350 .12 \\
\hline & & & 900 & -0.464 & 34.868 & 0.11 & -0.650 .46 \\
\hline
\end{tabular}

The fractions of sea-ice meltwater (fi) and river water ( $\mathrm{fr}$ ) are obtained from a mass balance calculation relative to average values of the BSBW sampled in $1995\left(0.21 \%\right.$ in $\delta^{18} \mathrm{O}$ and 34.83 in salinity) and applying a river water endmember representing average Arctic river runoff $(-18 \%$ in $\delta^{18} \mathrm{O}$ ). For further explanation see text.

these two extreme assumptions demonstrate the stability of the general finding that there is an enlarged brine contribution to 2006 BSBW relative to 1995 BSBW, and the calculated fractions that are obtained by applying the Arctic river runoff endmember of $-18 \%$ in $\delta^{18} \mathrm{O}$ (Table 2 ) can be considered as lower limits.

\section{Discussion}

Here we address the causes underlying changes in the BSBW properties from 2005 to 2006. Our overall goals in examining the upstream ice and atmospheric conditions are (i) to estimate their variations during translation of the BSBW from the Barents Sea Opening (BSO) to the northern Kara Sea and (ii) to reveal their potential impact on the BSBW downstream interannual variability observed between 1995, 2005, and 2006. Woodgate et al. (2001) and McLaughlin et al. (2002) were the first to infer the far-field effects of the Barents Sea through the analysis of the downstream propagating BSBW thermohaline signal modified by upstream ice and atmospheric events over the Barents Sea. Following this approach, we argue that a part of the BSBW interannual variability in the western Laptev Sea is due to modification of the BSBW inflow during its translation through the Barents and northern Kara seas.

\subsection{Upstream conditions: the introduction}

Outflow of the BSBW to the Eurasian Basin occurs along the eastern flank of the St. Anna Trough (Schauer et al., 2002a). The temperature and salinity of the BSBW outflow, derived from the typical CTD profile taken in July 1996 at the eastern flank of the St. Anna Trough, have core values of $-1{ }^{\circ} \mathrm{C}$ and 34.77 . These are within one standard deviation of the BSBW core regional mean obtained by averaging all available CTD profiles over the eastern flank 
of the St. Anna Trough (see Dmitrenko et al. (2008b) for more details). Comparison of the BSBW outflow regional mean $T-S$ properties to the BSBW long-term mean for the entire Barents Sea by Smolyar and Adrov (2003) reveals strong modification of the BSBW flow while crossing the Barents Sea. The regional means of temperature and salinity of the BSBW outflow, shown in Fig. 7, of $\sim-0.5 \pm 0.7^{\circ} \mathrm{C}$ and $\sim 34.81 \pm 0.04$, are substantially cooler and fresher than the BSBW flowing into the Barents Sea through the BSO with temperature and salinity of about $5-6^{\circ} \mathrm{C}$ and 35.06 (Furevik, 2001). In contrast to the BSBW outflow, the properties of the BSBW flow over the central Barents Sea, defined by the top right portion of $T-S$ line by Smolyar and Adrov (2003), are closer to the properties of the FSBW flow off Franz Josef Land (Fig. 7). The cooling of the BSBW as it propagates across the Barents Sea reflects the direct heat lost to the atmosphere; during winter the cooling can reach down to depths between 60 and $100 \mathrm{~m}$ or more (Schauer et al., 2002a). This process is also associated with the downward mixing of the low-salinity surface water that results in the freshening of the layer down to $\sim 100 \mathrm{~m}$ (Schauer et al., 2002a). In summary, about $75 \%$ of the Barents Sea outflow

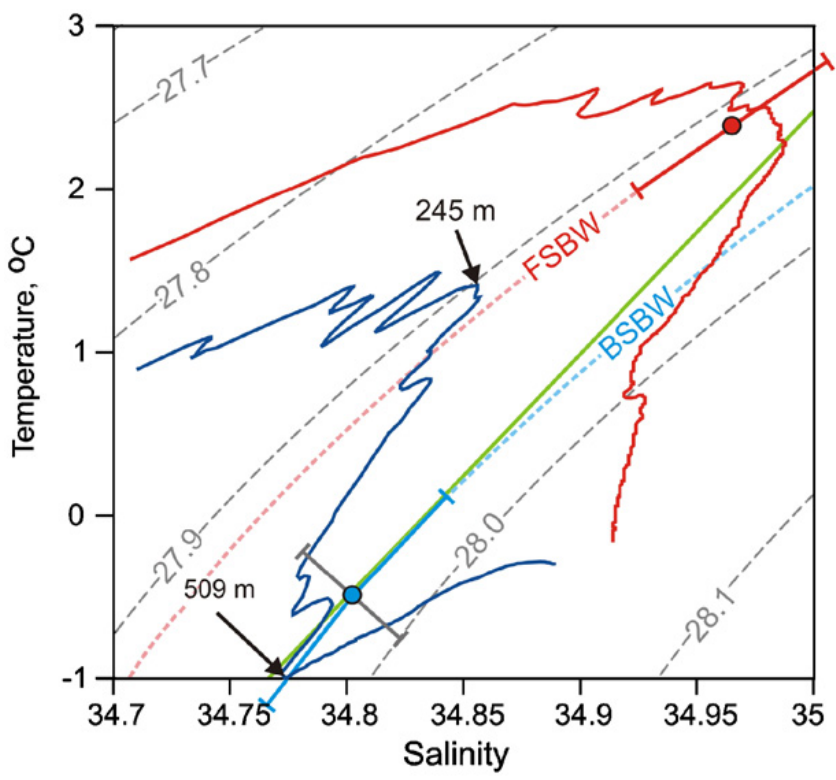

Fig. 7. The $T-S$ diagrams for typical CTD profiles taken through the BSBW core (blue: expedition ARKXII, July $1996,81.262^{\circ} \mathrm{N}, 70.945^{\circ} \mathrm{E}$ ) and the FSBW core (red: expedition NABOS, September $2006,83.032^{\circ} \mathrm{N} 59.936^{\circ} \mathrm{E}$, station \#44) upstream of their confluence in the northern Kara Sea (adapted from Dmitrenko et al., 2008b). Dashed lines are sigma-0 isopycnals in $\mathrm{kg} / \mathrm{m}^{3}$. Pink and blue dashed lines identify the mean sigma0 of the FSBW and BSBW, respectively, east from $90^{\circ}$ E. For the blue curve, the maximal temperature and salinity values of $\sim 1.4{ }^{\circ} \mathrm{C}$ and 34.84 , respectively, within sigma-0 of $27.85-27.95 \mathrm{~kg} / \mathrm{m}^{3}$ define the topographically trapped FSBW flow that is a recirculation from the AW inflow in the western St. Anna Trough. Dots show mean $T-S$ characteristics and along-isopycnal error bars show \pm one standard deviation in the core of the FSBW (red: $27.92 \pm 0.01 \mathrm{~kg} / \mathrm{m}^{3}$ ) and the BSBW (blue: $27.97 \pm 0.01$ $\mathrm{kg} / \mathrm{m}^{3}$ ) over the continental slope off the Franz Josef Land (red) and the eastern flank of the St. Anna Trough (blue). Black cross-isopycnal error bars indicate \pm one standard deviation of the mean BSBW sigma- 0 . See Dmitrenko et al. (2008b) for details of calculating regional means and associated standard deviations. Green line shows the long-term mean $T-S$ diagram for the BSBW in the Barents Sea adapted from Smolyar and Adrov (2003). to the northern Kara Sea has temperature below $0{ }^{\circ} \mathrm{C}$ (Schauer et al., 2002a). In fact, the thermohaline properties of the BSBW outflow may exhibit strong variability because of the variable BSBW inflow as well as sea-ice and atmospherically forced modification while the BSBW crosses the Barents Sea. For example, in the northern Barents Sea the temperature and salinity of the BSBW core varies from -1 to $0{ }^{\circ} \mathrm{C}$ and from 34.75 to 34.95 (Pfirman et al., 1994). The BSBW outflow sigma-0 of $\sim 27.97 \mathrm{~kg} / \mathrm{m}^{3}$, derived from the CTD profile taken at the eastern flank of the St. Anna Trough, is consistent with a regional mean as well as with a BSBW downstream mean reported by Dmitrenko et al. (2008b) and with a Barents Sea long-term mean by Smolyar and Adrov (2003) (Fig. 7). The BSBW outflow density ranges within $\pm 0.03 \mathrm{~kg} / \mathrm{m}^{3}$ (Fig. 7) providing evidence for the strong upstream variability (see also Table 1 in Smolyar and Adrov, 2003). In fact, over the western Barents Sea the sigma-0 isopycnal of $27.97 \mathrm{~kg} / \mathrm{m}^{3}$ associated with the BSBW core occupies the depth level of $\sim 70-140 \mathrm{~m}$, allowing the surface-driven mixing to affect the BSBW properties.

The BSBW inflow from the North Atlantic to the Barents Sea and its downstream propagation towards confluence with the FSBW are primarily wind driven (Loeng et al., 1993, 1997; McLaughlin et al., 2002; Karcher et al., 2003; Ingvaldsen et al., 2004; Ingvaldsen, 2005). The atmospheric circulation over the Barents Sea is dominated by the Icelandic low. The intensification of this low results in stronger wind from the south that drives inflow of the warm and salty North Atlantic water into the Barents Sea and its further transit through the Barents and northern Kara seas. The BSBW temperature, salinity, and density may vary with the input of North Atlantic water properties. For example, the typical interannual variability of inflowing BSBW salinity is 0.02 (Loeng, 1991; Schauer et al., 2002a), similar to increased salinity of $\sim 0.037$ observed through the BSBW core in the western Laptev Sea from 2005 to 2006. BSBW travel time between the western Barents Sea and the western Laptev Sea was estimated by Frank et al. (1998) to be about $5 \pm 0.5$ years, based on the tritium, ${ }^{3} \mathrm{He}$, and chlorofluorocarbon (CFC) tracers. In fact, during 1998-2004, the period when the downstream water sampled in 20052006 may have entered the Barents Sea, the BSBW inflow through the BSO demonstrates relatively stable and moderately positive temperature and salinity anomalies of about $0.4{ }^{\circ} \mathrm{C}$ and 0.02 , respectively (Ingvaldsen, 2005). This conclusion is also consistent with wind patterns. Through the period of 2000-2002 the meridional wind over the western Barents Sea exhibited moderately stable values slightly changing around zero (Fig. 7). A stable North Atlantic water inflow into the Barents Sea through the BSO during 1998-2004 (Ingvaldsen, 2005) supports our hypothesis that the downstream changes observed from 2005 to 2006 should be attributed to BSBW modification during its upstream transition rather than to BSBW inflow variability. Furthermore, BSBW inflow variability would result in simultaneous decrease or increase in both BSBW temperature and salinity as reported for the 1976-2004 period by Ingvaldsen (2005). Instead, however, the BSBW cooling observed from 2005 
to 2006 was accompanied by an increase in the salinity of the BSBW (Table 1).

We hypothesize that the BSBW sampled in 2006 was modified towards being cooler, saltier, and better ventilated relative to the conditions of 2005 due to upstream ice and atmospheric events over the Barents and northern Kara seas. The BSBW is cooled and lowered in salinity during its passage across the Barents and Kara sea shelves where the interaction with the atmosphere is most intense because of sea-ice cover seasonality (Schauer et al., 1997). Winter ice formation and summer ice melting also modify BSBW thermohaline properties (Martin and Cavalieri, 1989; Schauer et al., 1997). Because of changes in the preconditioning of these properties, or through the driving processes' interactions and feedbacks, the BSBW crossing the Barents and northern Kara seas may exhibit substantial interannual variability (see, for example, Pfirman et al., 1994).

Based on the $1.5 \mathrm{~cm} / \mathrm{s}$ AW boundary current velocity estimated by Polyakov et al. (2005), we assume that the BSBW travel time between the northern Kara Sea and the western Laptev Sea is about 1 year. This assumption, combined with the estimation of the BSBW travel time between the western Barents Sea and the western Laptev Sea by Frank et al. (1998), requires a residence time in the Barents and northern Kara seas between about 1990 and 1994, 2000 and 2004, and 2001 and 2005 for the BSBW sampled downstream in the western Laptev Sea in 1995, 2005 , and 2006, respectively. We therefore examined the patterns of atmospheric circulation, SAT, and winter seaice cover over the Barents and northern Kara seas in 2001-2005, 2000-2004, and 1990-1994.

\subsection{Atmospheric forcing: wind field}

The eastward extent of the Icelandic Low towards the Barents and Kara Seas is associated with increase of cyclonicity in this region (Johnson et al, 1999) that results in positive meridional wind ( $V$-wind) anomalies and increase in the BSBW Ekman transport through the BSO towards the northern Kara Sea (Loeng et al., 1993, 1997; Ingvaldsen et al., 2004). These results are also confirmed by numerical modeling by Harms (1992) and Karcher et al. (2003). Therefore, the meridional wind patterns are believed to be critical for the BSBW upstream transition: shifts between prevailing positive (from the south) and negative (from the north) $V$-winds may substantially affect BSBW transition through the Barents and northern Kara seas. Over this area from 1999 to 2004 a 13-month running mean of monthly $V$-wind is consistent with a $2 \frac{1}{2}$ -year periodicity with positive and negative values from 1999-2001 and 2001-2004, respectively (Fig. 8). At the same time, from the end of 1999 to the beginning of 2004 the $V$-wind averaged only over the BSO demonstrates little change (Fig. 8). We speculate that the shift from positive to negative $V$-wind patterns that occurred during summer 2001 affected the BSBW transition through the Barents and northern Kara seas.

Shifts between prevailing positive and negative $V$-winds may result in shorter (at positive $V$-wind) or longer (at negative $V$-wind) BSBW upstream residence time. The $V$-wind data spatially averaged over the BSBW pathway from the BSO to the northern Kara Sea and temporally integrated through the BSBW transit time summarizes wind impact on the BSBW transition through the upstream domain. The monthly mean $V$-wind time series were calculated from the monthly NCEP wind data averaged over the Barents and northern Kara seas from 2000 to 2005 . This time series was employed to estimate the accumulated $V$-wind velocity by summing the monthly mean data through 2000-2004 and 2001-2005. The accumulated $V$-wind velocity is lower by $\sim 10 \mathrm{~m} / \mathrm{s}$ in 2001-2005 compared with 2000-2004. This difference defines a stronger northward wind during 2000-2004 than in 2001-2005. This result is not quantitatively sensitive by \pm 6 months (not shown), which is the uncertainty in transit time determination from the tracer age estimation by Frank et al. (1998). Furthermore, the difference in accumulated $V$-wind corresponds to a monthly mean $V$-wind speed of $\sim 0.83 \mathrm{~m} / \mathrm{s}$, similar to the monthly mean BSO $V$-wind speed of $\sim 0.80 \mathrm{~m} / \mathrm{s}$ (Fig. 8 ) that was associated with a substantial increase of BSBW inflow through the BSO in 1999-2000 (Ingvaldsen et al., 2004). These results suggest that upstream residence time for the BSBW sampled downstream in 2006 may have been longer than that of the BSBW sampled in 2005.

As for the BSBW sampled in 1995, a 4-year mean $V$-wind from 1990 to 1994 exhibits a relatively high value of about $0.34 \mathrm{~m} / \mathrm{s}$ compared with 0.10 and $-0.08 \mathrm{~m} / \mathrm{s}$ from 2000-2004 and 2001-2005, respectively. Note, however, that these differences do not exceed the $V$-wind standard deviation of $0.66 \mathrm{~m} / \mathrm{s}$.

The possible role of the winds implies a connection between the BSBW properties and the North Atlantic Oscillation (NAO), which influences the mean sea level pressure (SLP) in the Barents Sea, and therefore the average surface wind fields. A high positive NAO index is associated with stronger winds from the south over the Barents Sea, whereas during periods of negative index are characterized by a local maximum in the mean SLP leading to light and variable winds (Dickson et al., 2000; Ingvaldsen et al., 2004; Ingvaldsen, 2005). While there are similarities between the winter-time NAO index and the mean $V$-wind (not shown), it is clear that changes in the NAO do not explain the interannual variations in the meridional winds, and it is likely that the intense, short period wind events of cyclones passing through the area (Tsukernik et al., 2007) that are not represented in the NAO index, play an important role in transforming the BSBW in its transit across the Barents Sea.

\subsection{Atmospheric forcing: surface air temperature field}

The BSBW upstream interaction with a cooler (at $-5.4^{\circ} \mathrm{C}$ mean SAT) atmosphere results in BSBW heat loss. Here we will examine the patterns of SAT variability over the Barents and northern Kara seas with a general goal of evaluating the SAT conditions during the upstream transit of the BSBW, which was sampled downstream in 1995, 2005, and 2006. 


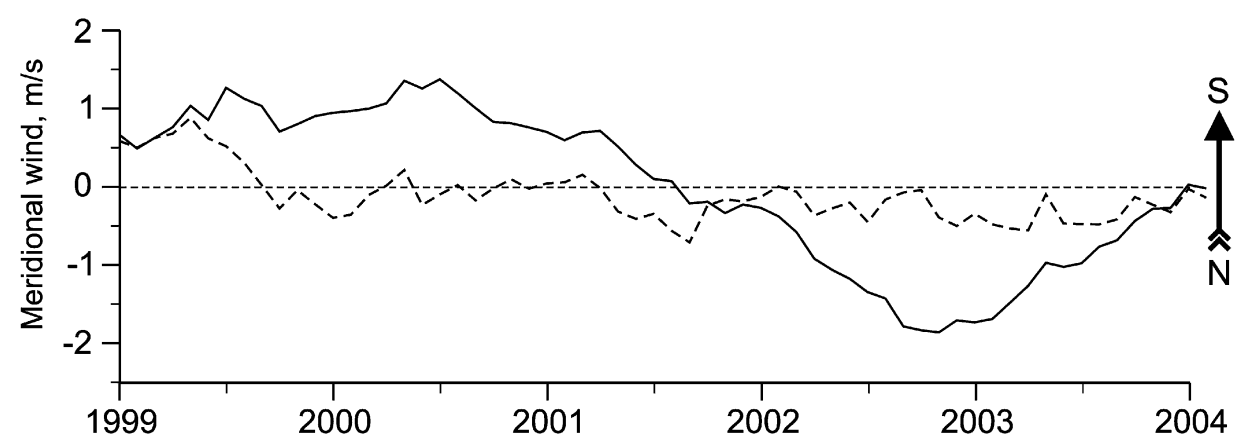

Fig. 8. Thirteen-month running mean of the NCEP-derived monthly meridional wind averaged over the Barents Sea Opening (BSO) between $10^{\circ}$ and $20^{\circ} \mathrm{E}$ longitude and $71^{\circ}$ and $77^{\circ} \mathrm{N}$ latitude (dashed line) and the entire Barents and northern Kara seas between $15^{\circ}$ and $52^{\circ} \mathrm{E}$ longitude and $71^{\circ}$ and $81^{\circ} \mathrm{N}$ latitude, and north of Novaya Zemlya to $81^{\circ} \mathrm{N}$ latitude further east between $52^{\circ}$ and $70^{\circ} \mathrm{E}$ longitude (solid line).

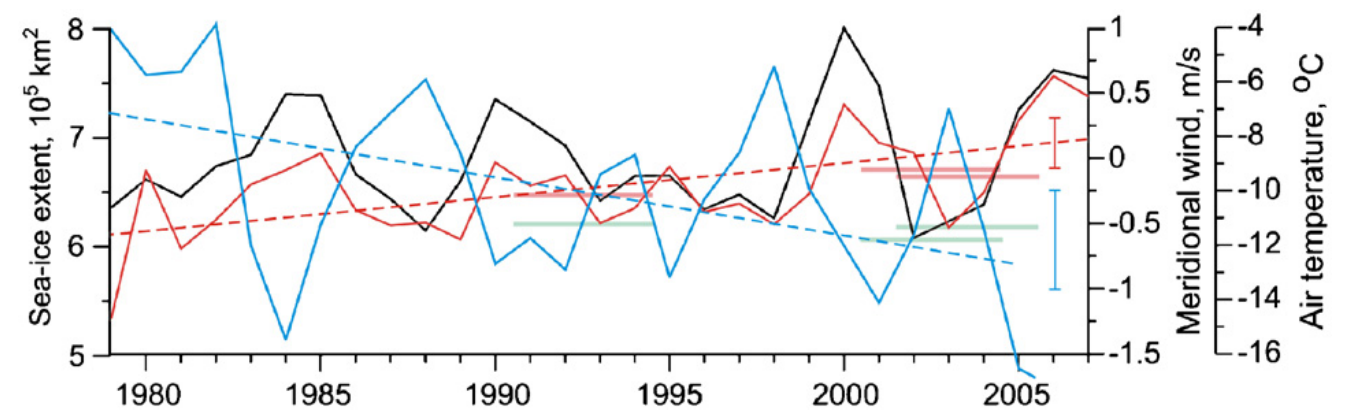

Fig. 9. Winter (October-May) mean time series of meridional wind (black) and surface air temperature (SAT, red) averaged over the Barents and northern Kara seas. The winter mean sea-ice extent (SIE) averaged over the same area is shown by blue. Dashed lines identify linear trends. Horizontal lines show four-year mean sea-ice extent and SAT for the residence time of the BSBW sampled in 1995, 2005, and 2006. Error bar shows one SIE and SAT standard deviation.

The time series of monthly mean SAT averaged over the Barents and northern Kara seas was derived from the NCEP data set for 1979-2007. The subsets of seasonal means were computed by averaging the monthly mean data from June to September and from October to May, when the SAT stably exhibits values above and below zero, respectively. The annual mean SAT time series were obtained by averaging the monthly mean data throughout the entire year. The SAT time series of winter mean is shown in Fig. 9.

The annual mean SAT exhibits a statistically significant (coefficient of determination $R^{2}=0.38$ ) positive trend (not shown) mainly due to a statistically significant $\left(R^{2}=0.33\right)$ SAT warming tendency in winter (Fig. 9). The SAT annual mean standard deviation $\left(1.3^{\circ} \mathrm{C}\right)$ is dominated mostly by winter variability with a standard deviation of $1.8^{\circ} \mathrm{C}$ (Fig. 9). Summer SAT shows no tendency with a long-term mean of $3.1^{\circ} \mathrm{C}$ and a relatively lower standard deviation of $0.6^{\circ} \mathrm{C}$ (not shown). A 4-year mean reveals a winter SAT of $-10.1,-9.2$, and $-9.5^{\circ} \mathrm{C}$ for the periods of expected upstream residence time for the BSBW sampled downstream in 1995, 2005, and 2006, respectively (Fig. 9). While the difference between these values does not exceed one standard deviation from the winter mean $\left(1.8^{\circ} \mathrm{C}\right)$, these SATs identify cooler conditions for the BSBW sampled in 1995.

\subsection{Sea-ice forcing}

Freezing and sea-ice extent (SIE) during winter appears to be an important influence on the transformation of
BSBW properties during BSBW transition through the Barents and northern Kara seas. The sea-ice insulates the warm underlying BSBW from the cold Arctic atmosphere and in freezing releases brine that increases surface water salinity. The sea-ice data are derived from the GSFC monthly mean sea-ice concentration data from 1979 to 2005 and seasonally averaged through the winter months when the SAT exhibits stable values below freezing (October-May). The SIE is defined over the Barents and northern Kara seas as the area of all $25 \times 25 \mathrm{~km}$ grid cells with ice concentration higher than $15 \%$. The time series of mean winter SIE (Fig. 9) is well correlated with that reported for the Barents Sea by Sorteberg and Kvingedal (2006).

While the SIE time series is strongly affected by variability with an apparent 3-4-year period and has a high standard deviation $\left(0.91 \times 10^{5} \mathrm{~km}^{2}\right)$, it is nevertheless dominated by a negative linear trend $\left(R^{2}=0.22\right)$, which is statistically significant at the $95 \%$ confidence level (Fig. 9). The $7 \%$ per decade of winter sea-ice lost over the Barents and northern Kara seas is qualitatively consistent with the 3.5\% per decade negative tendency of winter Barents Sea SIE reported by Sorteberg and Kvingedal (2006) based on a longer time series from 1967 to 2005 . The SIE difference between 1990-1994, 2000-2004, and 2001-2005 does not exceed one standard deviation; the highest SIE value is observed in $1990-1994\left(6.22 \times 10^{5} \mathrm{~km}^{2}\right)$, and the lowest value is observed in $2000-2004\left(6.10 \times 10^{5} \mathrm{~km}^{2}\right)$ (Fig. 9). For the six winter seasons of 2000-2005 all but 2003 demonstrate negative SIE anomalies of approximately one 
standard deviation. The year 2003 has a positive SIE anomaly of approximately the same magnitude. These sea-ice patterns result in a weak difference between SIE averaged for 2000-2004 and 2001-2005 (Fig. 9).

\subsection{Patterns of interaction between ocean, sea-ice and atmosphere over the Barents and northern Kara seas: impact on upstream transformation of BSBW properties}

Our simplified integrative approach employed in Sections 4.2-4.4 reveals general patterns of external forcing. Here we summarize our findings about external forcing factors including interactions and feedbacks in the context of their ability to impact the BSBW temperature, salinity, and isotopic properties during BSBW transit through the Barents and northern Kara seas. First, we consider the thermodynamic and dynamic-thermodynamic aspects of wind impact on the BSBW downstream thermohaline properties before we compare data of 1995, 2005, and 2006.

\subsubsection{Thermodynamic aspect}

The correlations of mean winter $V$-wind time series with mean winter SAT and mean winter SIE are 0.72 and -0.68 , respectively (both statistically significant at the $95 \%$ confidence level). This result is consistent with the summary by Loeng et al. (1997) that low air pressure over Barents Sea is accompanied by warmer SAT and reduced SIE. These correlations imply two possible patterns of wind-driven regularities. Wind from the south forces the sea-ice towards the Arctic Ocean resulting in a lower SIE during winters with prevailing winds from the south (Fig. 9). The reduced SIE indicates more open water and therefore the possibility of greater heat loss to the atmosphere, which has sub-zero SAT, and more brine release due to the formation of new sea-ice. However, to a first-order approximation, the winds from the south also bring warmer air masses, resulting in an SAT increase over the Barents and northern Kara seas (Fig. 9), which can result in a reduction in new ice formation via thermodynamic effects. Of these two opposing effects the increase in new sea-ice formation seems to be dominant because in all years that exhibit positive values of $V$-wind, the winter mean SAT always remains far below freezing (Fig. 9).

\subsubsection{Dynamic-thermodynamic aspect}

The BSBW transition through the Barents and northern Kara seas is believed to be sensitive to wind forcing (Harms, 1992; Loeng et al., 1993, 1997; McLaughlin et al., 2002; Karcher et al., 2003). Positive $V$-wind anomaly reduces BSBW transit time, but the reduced SIE may result in more intensive BSBW heat loss to the atmosphere, cooling, and increasing salinity due to more intensive seaice formation. A negative $V$-wind anomaly slows the BSBW transition, reducing heat loss and salt influx because the more extended sea-ice cover insulates the underlying BSBW. However, a longer residence time results in longer contact with the cooler atmosphere, apparently shifting the BSBW towards being cooler and saltier.

By comparing the 1995, 2005, and 2006 data we demonstrate in a second step that the cooler, more saline, and better-ventilated BSBW sampled in 2006 likely resulted from longer upstream translation through the Barents and northern Kara seas. We also show that regional warming of atmosphere and sea-ice retreat tend to disrupt the wind-driven dynamic-thermodynamic patterns described above. Finally, we project the results of comparison between 1995 and 2006 onto the recent findings from 2005 to 2006.

\subsubsection{5 versus 2006}

The distinct difference between meridional wind forcing in 1990-1994 and in 2001-2005 (with 0.34 to $-0.08 \mathrm{~m} / \mathrm{s}$, respectively) encourages us to use the analysis of oxygen isotope composition from 1995 and 2006 to diagnose the general tendency of the BSBW to be modified during upstream transition under different patterns of atmospheric circulation. We are interested in explaining the contribution of sea-ice brines to the 2006 data, which represents BSBW upstream transit time from 2001 to 2005 , relative to the 1995 data, which corresponds to BSBW upstream transit time from 1990 to 1994 . While the statistically significant correlation of -0.68 clearly indicates a negative linkage between winter mean $V$-wind and SIE, the sea-ice long-term negative tendency disrupts this relationship, and the SIE for the positive $V$-wind period of 1990-1994 is not statistically different from the negative $V$-wind-dominated period of 2001-2005 (Fig. 9). The linkage between $V$-wind and winter mean SAT exhibits the same pattern. $V$-wind and winter mean SAT are positively correlated, but the SAT long-term positive tendency (Fig. 9) disrupts this relationship: the SAT from 1990 to 1994 is lower than in 2001-2005. A contribution of $-0.3 \%$ to $-0.7 \%$ of sea-ice meltwater to the BSBW core in 2006 relative to 1995 was calculated. The negative fractions of sea-ice meltwater reflect a corresponding amount of brine added to the water column. This result clearly demonstrates that the accumulated effect of external forcing under negative $V$-wind conditions (2001-2005) tends to increase brine modification of the BSBW (most likely due to a longer BSBW residence time) rather than to diminish brine release to the BSBW due to warmer SAT associated with a positive SAT trend.

\subsubsection{5 versus 2006}

In terms of wind patterns, 2000-2004, with a moderately positive $V$-wind of $0.10 \mathrm{~m} / \mathrm{s}$, closely resembles 1990-1994. From this, and from the fact that based on oxygen isotope analysis the 2006 BSBW was found to be enriched in brine relative to 1995 , we speculate that the downstream interannual variability in BSBW properties between 2005 and 2006 is likely attributable to brine modification of the water sampled in 2006 during its longer upstream transit through the Barents and northern Kara seas. The SIE-related processes have likely little importance since the SIE difference between the 4-year winter means from 2000-2004 and 2001-2005 is estimated to be as low as $\sim 15 \%$ of SIE standard deviation 
(Fig. 9). The 4-year mean SAT also exhibits almost no difference between 2000-2004 and 2001-2005 (compare -9.2 to $-9.5^{\circ} \mathrm{C}$ ). Higher BSBW ventilation in 2006 (compare Fig. 3 for DO concentrations) is likely due to a longer BSBW sea-surface residence time in direct contact with the atmosphere, and also supports this speculation.

\section{Summary and concluding remarks}

We used data collected from a CTD survey over the continental slope of the Eurasian Basin of the Arctic Ocean for 2 consecutive years: 2005 and 2006. CTD data from 1995 were employed as a reference point for oxygen isotope analysis and evaluating atmospheric and sea-ice forcing. Over the Siberian continental margin the FSBW exhibits continuous dramatic warming beginning in 2004, but the BSBW demonstrates a contrary tendency to cool that is also confirmed by 2007 CTD observations from the R.V. Akademik Fedorov. Our data show that in 2006 the BSWB core was saltier (by 0.016-0.040), cooler (by $0.20-0.40{ }^{\circ} \mathrm{C}$ ), denser (by $\sim 0.05 \mathrm{~kg} / \mathrm{m}^{3}$ ), deeper (by $150-200 \mathrm{~m}$ ), and relatively better ventilated (by $7-8 \mu \mathrm{mol} / \mathrm{kg}$ of dissolved oxygen, or $1.1-1.7 \%$ of saturation) compared with 2005. The interannual variability of wind patterns over the Barents and northern Kara seas allows us to assume a longer upstream residence time for the BSBW sampled in the western Laptev Sea in September 2006 compared with that from September 2005. We speculate that through the increased sea-ice formation and net heat loss to the atmosphere a longer upstream residence time results in BSBW cooling, increasing salinity, and a higher rate of ventilation, as evident from our 2005-2006 downstream observations. Comparing $\delta^{18} \mathrm{O}$ and salinity data from the 2006 and 1995 BSBW clearly shows that in 2006 the contribution of brine added during sea-ice formation is larger. Based on our argument that in terms of the governing wind patterns the 2005 and 1995 BSBW exhibit a distinct similarity, we speculate that the 2006 BSBW is also enlarged in brine relative to the $2005 \mathrm{BSBW}$. Based on this assumption, an enlarged contribution of brine due to sea-ice formation caused the observed salinity increase in the 2006 BSBW and is consistent with the assumption of an increased upstream residence time as indicated by wind patterns and DO values.

There are some caveats to our analysis. The transit time estimate by Frank et al. (1998) is based on a single year (1993) evaluation allowing no consideration of the BSBW seasonal variability that in fact strongly affects properties of the BSBW inflow through the BSO (Furevik, 2001; Ingvaldsen, 2005). The sea-ice extent and atmospheric forcing conditions during upstream transit of the BSBW sampled in 1995, 2005, and 2006 were not sufficiently different to allow statistically reliable conclusions to be drawn. Presumably, elucidating the interplay between atmospheric circulation, ice-related processes, and precipitation and evaporation (which were not part of our analysis) that is not yet well understood being combined with a long-term downstream record of BSBW properties will substantially advance our knowledge.
While some of our discussion and conclusions are necessarily speculative, the data show an intriguing signal embedded in the two branches of the Atlantic Inflow into the Arctic Ocean that indicates the complexity of the subsurface physical oceanography and heat transport. Further research is needed to test our hypothesis that the properties of the BSBW inflow into the Arctic are determined by variable residence time and air-sea interactions in the Barents Sea and northern Kara Sea. This research should be based on modeling of the area and on improved in situ measurements, especially in the area of the confluence of the two branches in the mouth of the Santa Anna Trough.

\section{Acknowledgments}

The hydrographic observations in 2005-2006 were carried out within the working framework of the ongoing NOAA and NSF-funded IARC Program "Nansen and Amundsen Basins Observational System" (NABOS). ID and SK gratefully acknowledge financial support through the BMBF project "System Laptev Sea" (03G0639A). DB appreciates funds through the DFG Grant SP 526/3 and the BMBF 03G0639D project. NK was supported by a grant from the IMPRS-ESM (International Max Planck Research School on Earth System Modeling). VI was funded by the Frontier Research System for Global Change. PJM acknowledges support from the NSF (ARC 0743972). We gratefully acknowledge Ursula Schauer for CTD profiles taken in 1993-1996 from the R.V. Polarstern. The dissolved oxygen analysis and sampling for the oxygen isotope analysis in 2005-2006 were conducted by the hydrochemical group of the Arctic and Antarctic Research Institute.

\section{References}

Aagaard, K., 1989. A synthesis of the Arctic Ocean circulation. Ocean Modelling Rapports et Proces-Verbaux des Reunions, Conseil International pour 1 Exploration de Ia Mer 188, 11-22.

Aagaard, K., Woodgate, R.A., 2001. Some thoughts on the freezing and melting of sea ice and their effects on the ocean. Ocean Modelling 3. 127-135.

Bauch, D., Schlosser, P., Fairbanks, R.F., 1995. Freshwater balance and the sources of deep and bottom waters in the Arctic Ocean inferred from the distribution of $\mathrm{H}_{2}{ }^{18} \mathrm{O}$. Progress in Oceanography 35, 53-80.

Bauch, D., Erlenkeuser, H., Stanovoy, V., Simstich, J., Spielhagen, R.F., 2003. Freshwater distribution and brine waters in the southern Kara Sea in summer 1999 as depicted by $\delta^{18} \mathrm{O}$ results. In: Ruediger, S., Fahl, K., Fuetterer, D.K., Galimov, E.M., Stepanets, O. (Eds.), Siberian River Run-off in the Kara Sea; Characterisation, Quantification, Variability and Environmental Significance. Elsevier, Amsterdam, pp. 73-90.

Bauch, D., Erlenkeuser, H., Andersen, N., 2005. Water mass processes on Arctic shelves as revealed from $\delta^{18} \mathrm{O}$ of $\mathrm{H}_{2} \mathrm{O}$. Global and Planetary Change 48, 165-174.

Carmack, E., Macdonald, R., Perkin, R., McLaughlin, F., Pearson, R., 1995 Evidence for warming of Atlantic water in the Southern Canadian Basin of the Arctic Ocean: evidence from the Larsen-93 expedition. Geophysical Research Letters 22, 1061-1065.

Cavalieri, D., Parkinson, C., Gloersen, P., Zwally, H.J., 2006. Sea ice concentrations from Nimbus-7 SMMR and DMSP SSM/I passive microwave data. National Snow and Ice Data Center, Boulder, CO, USA. Digital media.

Craig, H., 1961. Standard for reporting concentrations of deuterium and oxygen-18 in natural waters. Science $133,1833-1834$.

Dickson, R.R., Osborn, T.J., Hurrell, J.W., Meincke, J., Blindheim, J., Adlandsvik, B., Vinje, T., Alexeev, G., Maslowski, W., 2000. The Arctic 
Ocean response to the North Atlantic oscillation. Journal of Climate 13, 2671-2696.

Dmitrenko, I.A., Polyakov, I.V., Kirillov, S.A., Timokhov, L.A., Frolov, I.E., Sokolov, V.T., Simmons, H.L., Ivanov, V.V., Walsh, D., 2008a. Towards a warmer Arctic Ocean: spreading of the early 21st century Atlantic water warmer anomaly along the Eurasian Basin margins. Journal of Geophysical Research 113 (C05023).

Dmitrenko, I.A., Kirillov, S.A., Ivanov, V.V., Woodgate, R., 2008b. Mesoscale Atlantic water eddy off the Laptev Sea continental slope carries the signature of upstream interaction. Journal of Geophysical Research 113 (C07005)

Ekwurzel, B., Schlosser, P., Mortlock, R., Fairbanks, R., 2001. River runoff, sea ice meltwater, and Pacific water distribution and mean residence times in the Arctic Ocean. Journal of Geophysical Research 106 (C5), 9075-9092.

Falkner, K., Steele, M., Woodgate, R., Swift, J., Aagaard, K., Morison, J., 2005. Dissolved oxygen extrema in the Arctic Ocean halocline from the North Pole to the Lincoln Sea. Deep-Sea Research I 52 (7), 1138-1154.

Frank, M., 1996. Tracer investigations on the circulation in the Eurasian Basin of the Arctic Ocean. Ph.D. Thesis, University of Heidelberg, Germany, 100pp. (in German).

Frank, M., Smethie, W.M., Bayer, R., 1998. Investigation of subsurface water flow along the continental margin of the Eurasian Basin using the transient tracers tritium, ${ }^{3} \mathrm{He}$, and CFCs. Journal of Geophysical Research 103 (C13), 30,773-30,792.

Furevik, T., 2001. Annual and interannual variability of Atlantic water temperatures in the Norwegian and Barents Seas: 1980-1996. DeepSea Research I 48, 383-404.

Ingvaldsen, R.B., 2005. Width of the North Cape current and location of the Polar Front in the western Barents Sea. Geophysical Research Letters 32, L16603.

Ingvaldsen, R.B., Asplin, L., Loeng, H., 2004. Velocity field of the western entrance to the Barents Sea. Journal of Geophysical Research 109, C03021.

Harms, I.H., 1992. A numerical study of the barotropic circulation in the Barents and Kara Seas. Continental Shelf Research 12 (9), 1043-1058.

Jakobsson, M., IBCAO editorial board members, 2001. Improvement to the international bathymetric chart of the Arctic Ocean (IBCAO): updating the data base and the grid model. Eos Trans. AGU, vol. 82(47), Fall Meet. Suppl., Abstract OS11B-0371.

Johnson, M.A., Proshutinsky, A.Y., Polyakov, I.V., 1999. Atmospheric patterns forcing two regimes of Arctic ice-ocean circulation: a return to anticyclonic conditions? Geophysical Research Letters 26 (11), 1621-1624.

Karcher, M.J., Gerdes, R., Kauker, F., Koberle, C., 2003. Arctic warming: evolution and spreading of the 1990s warm event in the Nordic seas and the Arctic Ocean. Journal of Geophysical Research 108 (C2), 3034

Loeng, H., 1991. Features of the physical oceanographic conditions of the Barents Sea. Polar Research 10 (1), 5-18.

Loeng, H., Ozhigin, V., Ardlandsvik, B., Sagen, H., 1993. Current measurements in the northeastern Barents Sea. ICES Paper C.M. 1993/C: 40, p. 22

Loeng, H., Ozhigin, V., Adlandsvik, B., 1997. Water fluxes through the Barents Sea. ICES Journal of Marine Science 54 (3), 310-317.

Macdonald, W., Paton, D., Carmack, E., Omstedt, A., 1995. The freshwater budget and under-ice spreading of Mackenzie River water in the Canadian Beaufort Sea based on salinity and ${ }^{18} \mathrm{O} /{ }^{16} \mathrm{O}$ measurements in water and ice. Journal of Geophysical Research 100, 895-919.

Martin, S., Cavalieri, D.J., 1989. Contributions of the Siberian shelf polynyas to the Arctic Ocean intermediate and deep water. Journal of Geophysical Research 94, 12725-12738.

McLaughlin, F.A., Carmack, E.C., Macdonald, R.W., Weaver, A., Smith, J.N., 2002. The Canada Basin 1989-1995: upstream events and far-field effects of the Barents Sea. Journal of Geophysical Research 107 (C7), 3082.

Melling, H., Moore, R., 1995. Modification of halocline source waters during freezing on the Beaufort Sea shelf: evidence from oxygen isotopes and dissolved nutrients. Continental Shelf Research 15, 89-113.

Mikalsen, G., Sejrup, H.P., 2000. Oxygen isotope composition of fjord and river water in the sognefjorden drainage area, Western Norway: implications for paleoclimate studies. Estuarine, Coastal and Shelf Science 50, 441-448.

Östlund, H., Hut, G., 1984. Arctic Ocean water mass balance from isotope data. Journal of Geophysical Research 89 (C4), 6373-6381.

Pfirman, S., Lange, M., Wollenburg, I., Schlosser, P., 1990. Sea ice characteristics and the role of sediment inclusions in deep-sea deposition: Arctic-Antarctic comparison. In: Beil, U., Thiede, J. (Eds.), Geological History of the Polar Oceans: Arctic Versus Antarctic. NATO Science Series C, vol. 308. Kluwer Academic, Dordrecht, pp. 187-211.

Pfirman, S.L., Bauch, D., Gammelsrød, T., 1994. The Northern Barents Sea: water mass distribution and modification. In: Johannessen, O., Muench, R., Overland, J. (Eds.), The Polar Oceans and their Role in Shaping the Global Environment: The Nansen Centennial Volume, AGU Geophysical Monograph, vol. 85. American Geophysical Union, Washington, DC, pp. 77-94.

Pfirman, S., Haxby, W., Eicken, H., Jeffries, M., Bauch, D., 2004. Drifting Arctic sea ice archives changes in ocean surface conditions. Geophysical Research Letters 31, L19401.

Polyakov, I.V., Alekseev, G.V., Timokhov, L.A., Bhatt, U.S., Colony, R.L., Simmons, H.L., Walsh, D., Walsh, J.E., Zakharov, V.F., 2004. Variability of the intermediate Atlantic water of the Arctic Ocean over the last 100 years. Journal of Climate 17 (23), 4485-4497.

Polyakov, I., Beszczynska, A., Carmack, E., Dmitrenko, I., Fahrbach, E., Frolov, I., Gerdes, R., Hansen, E., Holfort, J., Ivanov, V., Johnson, M., Karcher, M., Kauker, F., Morison, J., Orvik, K., Schauer, U., Simmons, H., Skagseth, Ø., Sokolov, V., Steele, M., Timokhov, L., Walsh, D., Walsh, J., 2005. One more step toward a warmer Arctic. Geophysical Research Letters 32 (17), L17605.

Quadfasel, D., Sy, A., Wells, D., Tunik, A., 1991. Warming in the Arctic. Nature 350, 385.

Rudels, B., Jones, E.P., Anderson, L.G., Kattner, G., 1994. On the intermediate depth waters of the Arctic Ocean. In: Johannessen, O.M., Muench, R.D., Overland, J.E. (Eds.), The Polar Oceans and Their Role in Shaping the Global Environment: The Nansen Centennial Volume, Geophysical Monograph, vol. 85. AGU, Washington, DC, pp. 33-46.

Rudels, B., Meyer, R., Fahrbach, E., Ivanov, V., Osterhus, S., Quadfasel, D., Schauer, U., Tverberg, V., Woodgate, R.A., 2000. Water mass distribution in Fram Strait and Yermak Plateau in summer 1997. Annales Geophysicae 18, 687-705.

Schauer, U.E., Muench, R.D., Rudels, B., Timokhov, L., 1997. Impact of eastern Arctic shelf waters on the Nansen Basin intermediate layers. Journal of Geophysical Research 102, 3371-3382.

Schauer, U., Loeng, H., Rudels, B., Ozhigin, V.K., Dieck, W., 2002a. Atlantic water flow through the Barents and Kara seas. Deep-Sea Research I 49 (12), 2281-2298.

Schauer, U., Rudels, B., Jones, E.P., Anderson, L.G., Muench, R.D., Björk, G., Swift, J.H., Ivanov, V., Larsson, A.M., 2002b. Confluence and redistribution of Atlantic water in the Nansen, Amundsen and Makarov basins. Annales Geophysicae 20 (2), 257-273.

Schauer, U., Fahrbach, E., Osterhus, S., Rohardt, G., 2004. Arctic warming through the Fram Strait-oceanic heat transport from three years of measurements. Journal of Geophysical Research 109 (C6), C06026.

Schmidt, G.A., Bigg, G.R., Rohling, E.J., 1999. Global Seawater Oxygen-18 Database 〈http://data.giss.nasa.gov/o18data $\rangle$.

Smolyar, I., Adrov, N., 2003. The quantitative definition of the Barents Sea Atlantic water: mapping of the annual climatic cycle and interannual variability. ICES Journal of Marine Science 60 (4), 836-845.

Sorteberg, A., Kvingedal, B., 2006. Atmospheric forcing on Barents Sea Ice. Journal of Climate 19 (19), 4772-4784.

Strickland, J.D.H., Parson, T.R., 1972. A Practical Handbook of Sea-Water Analysis. Bulletin of Fisheries Research Board of Canada, Ottawa, $311 \mathrm{pp}$.

Swift, H., Jones, E.P., Aagaard, K., Carmack, E.C., Hingston, M., MacDonald, R.W., McLaughlin, F.A., Perkin, R.G., 1997. Waters of the Makarov and Canada basins. Deep-Sea Research II 44 (8), 1503-1529.

Timofeev, V.T., 1957. Atlantic waters in the Arctic basin. Problemy Arktiki 2, 41-52 (in Russian)

Tsukernik, M., Kindig, D.N., Serreze, M.C., 2007. Characteristics of winter cyclone activity in the northern North Atlantic: insights from observations and regional modeling. Journal of Geophysical Research 112, D03101.

Woodgate, R.A., Aagaard, K., Muench, R.D., Gunn, J., Bjork, G., Rudels, B., Roach, A.T., Schauer, U., 2001. The Arctic Ocean boundary current along the Eurasian slope and the adjacent Lomonosov Ridge: water mass properties, transports and transformations from moored instruments. Deep-Sea Research I 48, 1757-1792.

Woodgate, R.A., Aagaard, K., Swift, J.H., Smethie Jr., W.M., Falkner, K.K., 2007. Atlantic water circulation over the Mendeleev Ridge and Chukchi Borderland from thermohaline intrusions and water mass properties. Journal of Geophysical Research 112, C02005.

Zhang, J., Rothrock, D.A., Steele, M., 1998. Warming of the Arctic Ocean by a strengthened Atlantic inflow: model results. Geophysical Research Letters 25 (10), 1745-1748. 